\title{
Campos: a capital sonhada de uma província desejada (1835-1897)
}

\section{Campos: The dreamed capital of a desired province. (1835 - 1897)}

Maria Isabel de Jesus CHRYSOSTOMO*

Resumo: Este trabalho discute as tentativas de Campos dos Goytacazes/RJ em se tornar uma capital política, dando destaque a três movimentos que correspondem, simultaneamente, a três momentos: o primeiro, desenvolvido num tempo longo correspondeu o da construção das imagens e representações que serviram de mote para a elaboração dos projetos de capital no século XIX; o segundo no ano de 1855, quando se esboçou um projeto de criação da província dos Goytacazes e, finalmente, o terceiro em 1890, quando Campos reivindica ser a nova capital do então Estado do Rio de Janeiro. Assim, acredita-se que os motivos que levaram recorrentemente a cidade de Campos a lutar pela mudança do seu estatuto administrativo, estejam associados aos mecanismos empregados pelas elites locais para construir uma imagem de lugar central. Neste aspecto, coloca-se em discussão que o projeto de se tornar capital constituiu-se em uma das estratégias dos atores locais para expandir a sua influência política a partir do controle do “chão”. Um movimento que forjou novas espacialidades, utilizando-se, via de regra, um discurso que associava o tema desenvolvimento ao de integração regional. Portanto, considero que o desejo de Campos se tornar uma capital refletia a ideia de domínio político desta localidade sobre as demais em função da concentração de poder político e administrativo desta cidade.

Palavras-chaves: Campos dos Goytacazes. Capital. Região. Cana-de- açúcar.

Abstract: This work discusses the attempts of Campos dos Goyatazes to become a political center. It will emphasize three movements, which correspond, in parallel, to three distinct moments in time: the first, developed over a long period, relates to the construction of images and representations that served as the motto for the capital build project during the 19th century; the second, in 1855,

\footnotetext{
Professora Adjunta de Geografia da Universidade Federal de Viçosa (Avenida Peter Henry Rolfs, s/n Campus Universitário 36570-000, Viçosa- MG). Mestre e Doutora em Planejamento Urbano e Regional (IPPUR/UFRJ). Este texto foi elaborado no âmbito do desenvolvimento do pós-doutorado na École de Hautes Études, com o apoio financeiro da CAPES - processo 4151/097. Agradeço a leitura atenta e as sugestões feitas pelo professor Laurent Vidal da Universidade de La Rochelle.
} 
corresponds to when a project to create the province of Goyatazes was initially drafted; and, finally, the third, in 1890, coincides with Campos claiming to be the new capital of what was, then, the state of Rio de Janeiro.

Within the study, I correlate the motives that led the city of Campos to recurrently fight for a change in its administrative status, to the mechanisms used by the local elites to construct, for the city, an image of geopolitical centrality and influence. I also discuss how the scheme to become the capital constituted just one of the strategies of local agents to expand their political influence, starting, literally, from a control of the "ground". This movement forged new spatialities, by using, without restrictions, any argument, which associated the themes of development with regional integration. Therefore indicating, I believe, that Campos' aspiration to become a capital merely reflected local ambitions for political dominance through the concentration of political and administrative power.

Keywords: Campos dos Goyatazes. Capital. Region. Sugarcane.

\section{“Campos capital do petróleo e da cana”}

O slogan acima, atualmente utilizado pelo governo municipal para representar política e economicamente a cidade de Campos, sugere uma reflexão sobre o antigo desejo desta cidade em ser tornar uma capital. Um sonho revivido por determinados agentes a partir da riqueza da cana-deaçúcar, atividade-símbolo da cidade desde o século XVIII. Um desejo e ao mesmo tempo uma estratégia política para obter recursos e poder. Manejada em diferentes tempos, de diferentes formas e por diferentes grupos sociais, o desejo das elites de Campos em se tornar uma capital foi sempre acompanhado por uma propaganda que reforçava a ideia da cidade ser o principal centro econômico da região norte fluminense. Embora tais imagens tivessem como rastro a riqueza proporcionada pela cana-de-açúcar, cumpriu o papel de escamotear os conflitos de terra e os benefícios conquistados pelas elites políticas e econômicas ao longo da história.

Serão discutidas, neste trabalho as tentativas de Campos dos Goytacazes em se tornar uma capital política, com destaque para três movimentos que correspondem, simultaneamente, a três momentos: o primeiro, desenvolvido num tempo longo correspondeu à construção das imagens e representações que serviram de mote para a construção dos projetos de capital no século XIX; o segundo ano de 1855, quando se esboçou um projeto de criação da província dos Goytacazes, movimento político que se inscreveu no interior das mudanças econômicas e políticas do Império escravista e se inseria em um contexto de transformação do papel econômico desta cidade e toda a 
sua região de influência. E, finalmente, o terceiro em 1890, já num contexto republicano, quando Campos reivindicou ser a nova capital do então Estado do Rio de Janeiro.

Considera-se que os motivos que levaram recorrentemente a cidade de Campos a lutar pela mudança do seu estatuto administrativo, estejam associados aos mecanismos empregados pelas elites locais para construir uma imagem de lugar central. Neste aspecto, pretende-se discutir que o projeto de se tornar capital foi uma das estratégias dos agentes sociais para expandir a sua influência política a partir do controle do “chão”. Um movimento que forjou novas espacialidades, utilizandose, via de regra, de um discurso que associa o tema desenvolvimento ao de integração. Portanto, considera-se que o desejo de Campos se tornar uma capital refletia a ideia de domínio político desta localidade sobre as demais em função da concentração do poder administrativo e de diferentes infraestruturas.

Levando em consideração o fenômeno que se pretende analisar, as seguintes questões se colocam para investigação: a) De que maneira os projetos de transformação de Campos Goytacazes em uma nova capital expressavam o poder político e econômico das lideranças locais nos diferentes contextos analisados?; b) Qual foi o papel exercido pelos atores locais no processo de constituição da ideia de ser capital?; c) De que forma a cidade de Campos, em função do seu histórico papel político e econômico, polarizava política e economicamente, as cidades, vilas e pequenos povoados localizadas ao norte fluminense, sul de Minas e Espírito Santo?; d) Como as propostas de se tornar capital encontravam eco junto às demais autoridades provinciais? e e) O que significava ser uma nova província durante o Império e ser a nova capital na nascente República?

\section{$1^{\circ}$ Movimento: a construção de uma imagem positiva da região de Campos}

Final do século XVIII e início do XIX: a despeito de existirem conflitos de terra envolvendo grandes e médios fazendeiros, posseiros, índios e a Câmara, a cidade de Campos passa a ter maior visibilidade política em função de certa estabilidade econômica e social propiciada pelo ótimo desempenho da cultura de cana-de-açúcar.

Localizada estrategicamente em uma área de intercâmbio comercial e de fluxo de escoamento de produtos advindos de Minas Gerais e Espírito Santo, pouco a pouco se transforma em um importante centro distribuidor de mercadorias e em uma praça mercantil de grande relevo na região norte da comarca do Rio de Janeiro. Em decorrência disso e de fatores ligados à questão da terra, Campos passa a receber muitos incentivos a partir de meados do século XVIII, especialmente durante o governo de Marquês de Lavradio. Este, adaptando a política de povoamento da Metrópole à região, estabelece um programa que visava ocupar novas terras, civilizar os índios, a partir da 
criação de comarcas, freguesias e novas aldeias. Também incentiva o estabelecimento e modernização de engenhos de açúcar e o fortalecimento das atividades de comércio externo e interno ${ }^{1}$. Para implementar tal política, a área passa a ser alvo permanente de visitações e expedições realizadas por viajantes estrangeiros contratados pela Coroa, missionários ${ }^{2}$ e aventureiros. O objetivo era fornecer informações sobre diferentes aspectos e avaliar a possibilidade de promover novos investimentos. Para atingir esta meta, formula-se um ambicioso plano de ocupação, cuja base de apoio é sustentada pela montagem de uma rede de instituições judiciárias e religiosas. São criados, assim, os postos de juízes de fora, capitães, ouvidores, mestre de campo ${ }^{3}$ etc, que passam a administrar pontos estratégicos do chamado "sertão dos índios bravios.” Esse novo corpo administrativo, juntamente com os viajantes, aventureiros, missionários e as elites locais, pouco a pouco pintam um novo retrato dos homens e da paisagem campista. ${ }^{5}$

Portanto, à medida que o poder da Coroa se enraizava e a região passava a ser reconhecida como área estratégica, a imagem de selvagens e rebeldes, até então característica dos habitantes, vai se modificando. Neste processo, o trabalho realizado pelos Mestres de Campo - que atuam como mediadores da Coroa - contribui, sobretudo, para a recriação de uma imagem que tende a valorizar as características ambientais e a docilidade dos habitantes da área. A repercussão desse movimento aparece indicada nos relatos do século XIX, entre os quais o de Pizarro.

[...] a cobiça do assucar transtornou inteiramente este paiz, e toda sua cultura [...] D’ahi proveio não só a opulencia em que se acha a terra, mas a differença, que se observa nos mesmos habitantes, passando de rústicos, e pela maior parte levantados à homens civis, muito aceiados, grandes negociantes, e fartos de numerário. (Pizarro em 1822, p. 117- 118).

\section{A matriz: a mémoria de Couto Reys e o nascimento de uma identidade regional}

Seguindo a pista de Soffiati (1997) considera-se, também, que a memória do capitão Manoel Couto Reys, elaborada em $1785^{6}$, por ter sido total ou parcialmente reproduzida nos futuros relatos sobre Campos, foi o ponto de partida para a criação e recriação de uma imagem que associava a prosperidade e riqueza, às características da paisagem da região.

He o terreno do Distrito dos Campos Goiatacaz, como dissemos, o mais fecundo, que se pode considerar para todo o gênero de plantas do Brazil [...] (Manuscritos ... op.cit. p.38)

"Huma das mayores maravilhas, que se contempla nesta terra baixa de que temos tratado, He a que vou relatar. Tendo a sabia experiência ensinado aos homens, que a procurão em qualquer Clima, tempos, ou estações próprias em que se devão agricultar diversas qualidades de plantas, e aqui conheção o mesmo, succede, que, independentes daquella precizissima, e importantíssima escolha, todo, todo o anno 
se agriculte sem excepção e seja a terra tão liberal que ofereça mimozos frutos ao seu lavrador. (Idem, p.39)

Tal perspectiva apontava também para o nascimento de uma ideia de grandeza regional, propiciada, sobretudo, pela localização, pelo comércio do então Distrito de Campos e pela existência de uma vasta rede hidrográfica ${ }^{7}$. Neste caso, destaca-se o relato de Couto Reys ao demonstrar o papel catalisador da cidade de Campos frente às demais localidades do seu entorno.

Hé a Metropoli deste Districto, a mais rica, e populoza de todas as sugeitas ao Rio de Janeiro; sustentada e engrandencida por um florescente comercio agitado pelos productos de todos os lugares seos subjacentos. Esta situada sobre a planice da Margem Meridional do Paraíba, distante do mar 6 legoas esforçadas. Pertense a Comarca da Capitania do Spirito Santo. Contem dentro em si 891 fogos incluzive 45 loges de mercadores, muito bem surtidas de importantíssimas fazendas, 59 tabernas, e 5 Cazas de louça vidrada. (MANUSCRITOS... 1785, p. 52).

Nas “intenções práticas” deixadas em seu relato há recomendações de como melhor aproveitar a terra, a economia e os seus homens, principalmente no que diz respeito à rede fluvial. Este aspecto é particularmente apontado quando Couto Reys ressalta o abandono dos rios, anteriormente utilizados para a navegação. Portanto, o melhor aproveitamento da rede fluvial para expandir a economia da cidade e região pode ser considerado como uma das principais ideias que visavam ampliar a liderança da cidade de Campos.

Se a nossa vergonhosa inércia - digna de lástima - não fora tão continuada, poderse -ia com o tempo, aplicação, e forças, reduzir a campo perfeito, o que agora pela causa referida, é defeituoso: com este importantíssimo beneficio, lograriam os futuros moradores a beleza de agradáveis campos, a de uma apreciável, e utilíssima navegação para mais pronta exportação dos seus gêneros; teriam juntamente a escolha das melhores situações em terras fertilíssimas, mais, e menos altas, para edificarem suas casas, suas lavouras, e criações: abundância de madeiras para fornecimento das suas fábricas, para seu comércio, e finalmente floresceriam com todos as vantagens, que o bom lavrador pode apetecer. Mas a desordenada cobiça, ambição, e extravagância dos homens [...], é a causa de se conservar este rio despovoado [...]

(SOFFIATI, 1997, p.15-16 apud: MANUSCRITOS...). In. Manuscritos de ...(1785). Rio de Janeiro: Arquivo Público do Rio de Janeiro, 1995.

É, talvez, daí que tenha nascido o projeto, tantas vezes propalado no século XIX, de Campos ser o local que melhor reúne condições de comandar política e economicamente as áreas de entorno. Também ideia que um maior investimento na rede hidrográfica seria o caminho para ampliar a riqueza de toda a região.

Em síntese, a menção às propostas de Couto Reys tornou-se comum nos discursos sobre a região, sendo seu emprego frequentemente utilizado para justificar os projetos de abertura de 
estradas e canais. Tornou-se, assim, uma das características marcantes das propostas elaboradas pelas lideranças no século XIX a incorporação de uma extensa área de reserva, passando a ser quase natural associar o seu destino aos projetos das lideranças campistas. Em diferentes contextos, isto significou para os moradores destas áreas, acompanhar ou apoiar os projetos pensados pelos líderes de Campos. Portanto, o olhar lançado pelo capitão e a maneira de descrever os diferentes aspectos que caracterizavam a região inauguram um gênero narrativo que foi imitado por vários atores que descreveram a área nos séculos seguintes. Com isso, para justificar a necessidade de controlar e incorporar novos espaços durante quase todo o século XIX e mesmo o XX se propagandeou nos relatos, memórias e jornais, o discurso que insistia em ressaltar a fertilidade dos solos, a abundância dos rios e a opulência e desenvolvimento da cidade/sociedade campista.

\section{A reprodução da imagem positiva de Campos no alvorecer da Independência}

Frente a uma situação de crise instaurada após a Independência e durante o período regencial, este olhar positivo da população, mais do que omitir a realidade (pois na área os problemas fundiários não cessavam) foi estratégico para reforçar a ideia de colaboração da elite campista aos projetos emanados pelo poder central. Por isso essas imagens e representações do povo e da natureza foram estrategicamente manipuladas, sobretudo por meio dos jornais locais, para legitimar sua filiação ao partido moderado. Os propagandistas destas imagens ou eram ou estavam diretamente vinculados à geração enraizada de políticos que construíram fortunas com o açúcar e que se transformaram nos barões ou viscondes, graças às alianças políticas que foram costuradas no alvorecer do Brasil Império. E é essa “civilização do açúcar”, como mencionava Alberto Lamego, que com o interesse de conferir maior visibilidade à região, emprega todos os recursos para transformar a cidade num polo regional no norte da província.

Nesse movimento, o discurso que assinalava a riqueza da área é manejado cada vez mais para justificar os projetos de integração de novos espaços, até então considerados vazios ou inadequadamente ocupados. Foi por isso, que o projeto em voga durante quase todo século XIX era ampliar o uso das vias naturais para articular os centros locais de comércio às diferentes áreas produtivas. Ressalta-se, ainda, que grande parte das áreas propostas para a implementação deste programa era ocupada por posseiros e índios. ${ }^{8}$

A propaganda em torno da ocupação e potencialização de novas áreas foi feita por muitos líderes locais, mas sem dúvida, após a Memória escrita em 1819 por José Carneiro Silva, ${ }^{9}$ estas e outras ideias ganharam maior visibilidade junto às autoridades centrais. Portanto, tal documento, 
portanto, uma nova etapa no processo de divulgação das riquezas da região e da necessidade de fortalecer a sua economia. Talvez tenha sido por esta razão que o coronel Carneiro da Silva - futuro Visconde de Araruama - ao, iniciar a sua Memória afirmava que a cidade de Campos: “[...] pela sua opulencia, e fertilidade merece ser mais conhecido, do que commente he [...]” (SILVA, 1819, prólogo).

Utilizando-se em parte das descrições feitas por Couto Reys, Silva também justificava a opulência de Campos como fruto da potencialidade dos solos e da extensa rede hidrográfica.

Huma das mais interessantes provincias do agigantado Reino do Brazil felismente confiado ao Paternaes disvelos e cuidados de Nossa magestade, he sem duvida a dos Campos dos Goytacazes: a exportação do assucar, sua numerosa população e os caudalosos rios que a retalhão, a tornão sobremaneira consideravel (MEMÓRIA... JOSÉ CARNEIRO DA SILVA, 1819).

Associando tal aspecto à amabilidade dos seus habitantes, Muniz de Sousa, um viajante que percorreu a região entre 1827 e 1828, registrou e referendou o mesmo ponto de vista sobre as características ambientais da região:

Os terrenos de Campos são os mais fecundos, férteis, e productivos, que se podem considerar, como para a mandioca, milho, feijão, arroz, café, e outra qualquer plantação; sendo huma das suas boas qualidades a de não soffer os escandalosos estragos da formiga chamada de mandioca, ou saúva [...] A agricultura da Villa de S. Salvador dos Campos dos Goytacazes he de huma vantagem consideravel, o que se deve á fecundíssima liberalidade dos terrenos, que como empenhados a suavisar o trabalho do lavrador, que os cultiva, liberrimamente produzem os germes vegetativos que sobre elles se diffundem.(SOUZA, 1834, p.117).

Como se pôde notar, estas e outras descrições da área reproduzidas e propagandeadas, tanto por agentes locais como por viajantes e missionários que passaram pela região no século XIX, reforçam, de certa forma, as propostas do manuscrito de Couto Reys, isto é, o desejo de aumentar a fluidez dos rios e canais, de ocupar as áreas consideradas vazias e de expandir a produção econômica. Nestes discursos, os atributos ambientais e sociais da cidade são manejados para justificar tanto a riqueza como a suposta capacidade de espraiá-la pela área de influência. Neste caso, observa-se a construção de uma identidade regional forjada pela ideia da existência de uma fertilidade inigualável dos solos e a capacidade de fluidez dos rios e lagoas.

Esta matriz argumentativa foi empregada em quase todos os momentos para justificar os projetos de Campos em se tornar capital. Conforme será demonstrado, uma característica que se tornou comum nos movimentos em prol da capitalidade foi a de imaginar um espaço ideal, no caso uma área integrada de produção e abastecimento comandada por Campos. Portanto, tanto a projeção 
do espaço da capital passou a ser utilizado como argumento para solucionar as diversas crises política e social enfrentadas ao longo do século XIX como instrumento para implementar os projetos pensados pelas elites para a região de entorno.

\section{A difusão da ideia de ordem: os jornais de Campos no alvorecer do Império brasileiro}

Desde quando a administração portuguesa se instalou no Rio de Janeiro muitas mudanças ocorreram no interior fluminense, em especial na cidade de Campos. Entre as várias medidas administrativas que foram adotadas a partir deste evento, assinala-se a construção de novas estradas. Tal processo concorreu para uma maior integração desta área com a Corte e Minas Gerais, fortalecendo política e economicamente os grupos locais envolvidos com a questão do abastecimento interno. ${ }^{10}$ Como analisado por Alcir Lenharo (1993), os integrantes das "tropas da moderação”, da qual faziam parte as forças políticas de Campos, participaram ativamente dos principais acontecimentos políticos que se desdobraram durante a Abdicação e na Regência, organizando-se, mais tarde, junto aos moderados $^{11}$. Defendendo a maior participação no comércio de cabotagem, no tráfico negreiro, na ocupação de cargos administrativos e nos negócios de estancos (a exemplo do sal e da madeira), estes grupos aliaram-se à Coroa desde o período joanino, e, inicialmente, ao $1^{\circ}$ Imperador.

No caso das elites de Campos, ora assumindo um caráter mais exaltado e defendendo bandeiras supostamente mais democráticas, ora um tom mais moderado, durante os anos conturbados que sucederam a Independência, estas elites penetraram paulatinamente nas redes de poder e se cristalizaram no setor da administração. Deste modo, a construção da ideia de colaboradores da nova ordem política, forjou-se neste contexto, isto é à medida que os líderes da cidade confrontavam as suas ideias e projetos políticos com chamada “questão nacional”. É por esta razão que, desde os primeiros jornais de Campos, uma ou duas páginas eram reservadas para apresentar e se posicionar sobre assuntos que implicavam diretamente nos rumos da política brasileira, como por exemplo, a escarnada luta entre os líderes do partido moderado e exaltado durante a fase regencial ${ }^{12}$.

Todos conhecem sabem os dannos, que o Brasil tem soffrido, e continua a soffrer por causa dos partidos; assim como não ignorão, que elle não póde dar um passo adiante, sem haver união, d'onde nasce a força; e por conseguinte convem dar de mão a caprichos, e vindictas, á fim de poder progredir a causa Publica [...] He necessário, tornamos a dizer, renunciar ódios privados, e caprichos vãos á bem da causa pública; as nossas circumstancias não são boas; e por tanto devemos todos concorrer para salvar a Patria, antepondo a sua prosperidade aos nossos interesses 
particulares, a nossa soberba e ambição [...] (O RECOPILADOR CAMPISTA, vol. 1 03/10/1835, no 72, p.2).

Embora no início do século XIX as elites de Campos não contassem com instrumentos sistemáticos de difusão de suas ideias, a propaganda política foi reforçada entre os anos de 1830 e 1840, quando os jornais O Campista (1834) e O Recopilador Campista (1835), os primeiros da cidade, ${ }^{13}$ passaram a circular com maior frequência. A maior organização da imprensa campista significou, em um primeiro momento, o apoio tácito aos políticos que apregoavam a necessidade de recuperar a “ordem pública”. Evocando, assim, um papel de representante da “opinião pública”, tais jornais declaravam, desde os seus primeiros números, a sua adesão ao partido Moderado:

[...] cabe aqui dissermos que por principios abraçamos e pertencemos ao partido moderado, porque desejamos que sejão as leys as únicas vingadoras do crime, e não nossas paixoens (O CAMPISTA, vol. 1, 4/01/1834)

He já sabido que a Opinião moderada triumphou plenamente no Collegio de Campos; na eleição dos Deputados a Assembléia provincial, o que não deixou de irritar sobremaneira os homens do partido exagerado. Elles são porem alli um numero tão pequeno e de tão diminuta influencia que não podem causar receio, embora a violência de caráter de alguns podesse arrastar outros num passo imprudente. (O RECOPILADOR CAMPISTA, v. $1,10 / 01 / 1835)$.

O mesmo Decreto de criou a província do Rio de Janeiro ${ }^{14}$ deu nascimento à cidade de Campos dos Goytacazes, até então denominada vila de São Sebastião. ${ }^{15}$ A sua autonomia política significou a um só tempo, a incorporação do seu território aos limites do Rio de Janeiro e a afirmação de um novo estatuto político e econômico junto à Assembleia provincial fluminense. ${ }^{16}$

Na realidade, o debate sobre a autonomia do Rio de Janeiro ${ }^{17}$ expunha uma situação de crise política no Brasil e o impacto das manifestações contrárias ao Ato Adicional promulgado em 1834, que aumentou o poder das Assembleias. ${ }^{18}$ Portanto, a contrariedade inicial de muitos políticos a autonomia política da província do Rio de Janeiro justificava-se pela instabilidade política e pelo receio da sobreposição dos poderes regional e central. Ainda que concordando com a opinião dos moderados em relação aos “abusos” praticados em algumas províncias, o editor do jornal $O$ Recopilador Campista, demonstrava a sua adesão a proposta de autonomização administrativa da província do Rio de Janeiro:

Em quanto ao Acto Addicional, convencidos estamos que os males não provirão das faculdades n'elle concedidas, e só do abuso que d'elle queirão fazer. Pois bem, cortem-se as azas d'essas Assembléas que queirão voar alem da orbita de seus poderes; quando seja de mister interpretal-o, predomine a necessidade de centralisação, e progrediremos sem sustos. 
Nos Presidentes, uma vez que sejão homens discretos, e da confiança do Governo central, na Assembléa Geral, uma vez que seus membros sejão Deputados da Nação e não Deputados da Provincias, correctivo seguro se dará a quaesquer desmandamentos que aqui ou alli appareção. (O RECOPILADOR CAMPISTA, vol. 1 30/09/1835, no. 71, p.2).

Portanto, quando começaram a se esboçar as medidas consideradas mais repressivas visando conter os "focos de rebelião", os políticos de Campos desempenharam um papel central, pois se aliaram à proposta de interpretação do Ato Adicional, assim como ao Golpe da Maioridade. ${ }^{19}$ Esta adesão ao Imperador é assinalada no jornal o Monitor Campista, que durante quase todo o ano de 1840 editou matérias exaltando D. Pedro II, notadamente nos dias e meses que sucederam a sua coroação. A exemplo, em matéria editada no dia 14/08/1840, o jornal divulgou os festejos realizados em praça pública durante os quatro dias que sucederam a coroação de D. Pedro II $^{\circ}$, especialmente a representação de uma peça teatral, intitulada “A maioridade do Sr. D. Pedro II"; na qual, um dos personagens - “o povo campista” - declamava o seguinte verso: ${ }^{20}$

\author{
Sobe ao Throno Brasileio \\ Do Brasil filho querido; \\ Firma nelle a Liberdade \\ Do teu povo agradecido \\ Só Pedro e Constituição \\ O Brasil podem Salvar \\ Quem governa aos dezoit' annos \\ Pode aos quinze governar. \\ (O MONITOR CAMPISTA, 14/08/1840, p.3).
}

Assim, mais integrados às redes de poder que se cristalizaram após as medidas do Regresso, os políticos da cidade de Campos manifestavam mais incisivamente os seus projetos junto à Assembleia provincial, instituição que se tornou um dos principais organismos de gestão da política centralizadora do Império. Entretanto, os reclames de Campos passaram a ser sistematicamente propagandeados em nível local, sobretudo após a fundação do jornal Monitor Campista. ${ }^{21}$ Este é um movimento que ocorreu paralelamente a transformação de vila em cidade, $^{22}$ à ebulição de ideias e projetos para melhorar o trânsito na região ${ }^{23}$ e, conforme já mencionado, à conquista da autonomia política da província do Rio de Janeiro e o seu fortalecimento como principal espaço econômico e político do Império. 


\title{
O nascimento do campista: a cristalização da identidade regional
}

\begin{abstract}
Sonhamos para Campos, num futuro próximo, uma terra salubre, de culturas variadas, mais opulenta do que a terra lombarda, onde tão bem se sabe secar as lagoas. Que falta para isso? O espírito campista é vivo, ousado e penetrante. Os costumes são afáveis hospitaleiros, as maneiras corteses. Abre-se para o forasteiro a casa humilde com tanta graça e cordialidade como a bela fazenda do barão de Carapebús. Enfim, o povo é laborioso e a terra se presta a tudo. Que falta, pois? Que é preciso? Um pouco de energia, campistas, e justificareis a verdade dos índios. Vossa terra se chamará com propriedade - o campo das delícias. (CHARLES RIBEYROLLES, 1859, p. 25).
\end{abstract}

As palavras de gravadas em 1859 sinalizam justamente esse momento de afirmação de um novo sujeito histórico - o campista - um agente portador de qualidades inerentes ao índio Goytacaz. O seu desejo, manifesto pela conquista da autonomia política da cidade (e da representação disto por meio da adjetivação de Goytacaz) ilustra também a continuidade de uma articulação dos representantes locais (vereadores - fazendeiros - comerciantes) para ocuparem uma melhor posição política junto à recente Assembleia do Rio de Janeiro.

Conforme já mencionado, é possível inferir que apesar da construção desse sujeito ser fruto de um trabalho esculpido desde o final do século XVIII, esta se manifesta mais claramente quando os representantes de Campos, articulados com os municípios da região norte, se organizam para obter maiores privilégios na nova Assembleia provincial fluminense, utilizando-se, via de regra, de um discurso que assinalava o desejo de integrar a região para fortalecer a economia ainda adormecida de áreas contíguas.

Considera-se, portanto, que a defesa dos interesses, ainda que não muito articulada, dos municípios do norte fluminense na nova Assembleia cristalizou uma ideia de região - uma “consciência” regional. Essa consciência contou com várias estratégias, entre as quais a de promover uma propaganda sistemática (positiva ou negativa) dos atributos ambientais e sociais que caracterizam a cidade e as vilas de entorno. O objetivo, nem sempre explícito, foi tanto dar visibilidade à região, como recuperar recursos. Assim sendo, em um momento de reajustamento das fronteiras administrativas e civis e de construção de um poder provincial, as lideranças campistas constroem uma ideia de região, reinventando historicamente uma relação de contato social e econômico com as áreas de entorno.

Tal movimento teve como um dos marcos deflagradores a discussão sobre a importância da cidade em sediar a nova capital da província, já que era a mais rica do Rio de Janeiro. A candidatura de Campos deflagrou uma disputa histórica com a cidade de Niterói e Santo Antônio de Itaboraí.

A expressiva liderança política exercida por Campos no norte fluminense e o seu papel de grande produtor de açúcar e de centro abastecedor da província do Rio de Janeiro pode ter 
contribuído para reforçar a ideia de que a nova capital da província devesse ser um local “verdadeiramente fluminense”, já que melhor representava essa nova identidade regional. Do outro lado, a cidade de Niterói, sua concorrente no projeto e futura vencedora, era identificada como um espaço de costura das grandes questões da Nação, quase uma extensão da Corte, portanto, inadequado para exercer o papel de representante de uma nova instância política, cuja economia caracterizava-se pela grande produção do açúcar e do café (GOUVÊA, 2008). Campos perde a disputa, mas consegue, do mesmo modo que Niterói e Parati, o status de cidade em $1835 .{ }^{24}$

Esse novo status de cidade conferido a Campos correspondeu não só a uma mudança na relação política e administrativa, mas também em seu ethos, movimento que se observou a partir de uma propaganda mais sistemática feita pelos jornais, em relação ao seu papel como polo de desenvolvimento do norte fluminense. Forjava-se, neste caso, uma identidade que associa a sua riqueza à missão de integrar uma rede de vilas, povoados e cidades em torno do seu comércio, que era notoriamente o mais expressivo da região norte. ${ }^{25}$ A qualidade de seus solos e a grande produção açucareira continuavam a ser apresentados como atributos que singularizavam Campos das demais áreas do Rio de Janeiro.

Ressaltar a importância da região, ora representando-a como uma área de grande potencialidade, ora como local degradado por falta de investimento e patriotismo dos cidadãos foram estratégias utilizadas pelas lideranças políticas para tanto incentivarem o que era considerado “a defesa do bem público” como para obterem recursos adicionais do governo central e provincial. De certa forma, as propostas das elites locais em transformar Campos num centro econômico foram lapidadas a partir da sistemática projeção da cidade como modelo de progresso e desenvolvimento regional. E, sem dúvida, nessa dinâmica de popularização da chamada “opinião pública”, as obras e investimentos em canais fluviais e estradas ganharam destaque nos debates referentes à melhor forma de promover o desenvolvimento econômico no norte fluminense. Neste aspecto, são ilustradoras as várias matérias publicadas no ano de 1834, no jornal O Campista. Em uma destas, o editor do referido jornal comentava os benefícios da abertura do canal Campos-Macaé para economia das localidades circunscritas entre Minas Gerais, Cantagalo e Macaé:

Nossas relações comerciaes em fim com a interessante Provincia de Minas mais se entrélaçará: porque tendo os mineiros um porto de embarque em Machaé situado a pequena distancia de Cantagalo, e meios de transformarem por água os seus gêneros para Campos, affuirão em amior quantidade para ali, evitando atravessarem os matos quase dezertos entre Cantagallo e Campos: e a Villa mesmo de Machaé não ganharia pequeno incremento. [...] (O CAMPISTA, vol.1 22/02/1834, no 15). 
O primeiro movimento político de Campos para se tornar a nova capital da província foi, portanto, caracterizado pela apresentação de projetos que visaram integrar as cidades e vilas por meio das vias fluviais, para facilitar o desenvolvimento da produção agrícola, do comércio e das atividades administrativas e, finalmente, para garantir a manutenção dos recursos necessários ao município. Cacife político para propor e sustentar os projetos é que não faltava, pois, conforme estudos realizados por Gouvêa (2008), por um longo período - 1836 a 1889 - os representantes de Campos eram majoritários na Assembleia. ${ }^{26}$ Então, o desejo de ser uma nova capital sinalizava a posição de destaque ocupada pelas lideranças do norte fluminense frente às decisões tomadas pelo executivo e legislativo provincial. Um movimento que se consagrou a partir da difusão de uma imagem positiva da região e do convencimento dos entes legislativo e executivo da necessidade de fortalecer economicamente a área, considerada à época chave do progresso da região norte do Rio de Janeiro. Isto significou, em um primeiro momento, a adoção de uma medida administrativa que foi a retenção das rendas municipais e a isenção de pagamento de taxas ao governo provincial. Oportuno, neste caso, mencionar que já na $1^{\text {a }}$ legislatura - anos 1838 e 1839 - a cidade, assim como a sua região de influência (São João da Barra e São Fidélis), conseguiu obter o privilégio de não repassar para os cofres provinciais a renda arrecadada por meio dos impostos sobre a exportação de açúcar. ${ }^{27}$ Tal medida, que foi contestada muitas vezes na Assembleia, assegurou a primeira posição para Campos por quase todo o século XIX, em termos de arrecadação. (GOUVÊA, 2008) ${ }^{28}$.

Cabe ressaltar, ainda, que o movimento de reajuste das fronteiras políticas e administrativas da província do Rio de Janeiro fortalece o papel central ocupado pela cidade de Campos, pois, direta e indiretamente, a gestão dessas áreas de entorno torna-se cada vez mais subordinada a este município. Portanto, é digno de nota que o movimento de definição das fronteiras territoriais do Rio de Janeiro, a partir de todo um debate sobre a existência de uma “identidade regional” esteve ligado à própria definição da cidade de Campos como principal polo econômico e administrativo da região norte.

\section{$2^{\circ}$ Movimento: Campos capital da província dos Goytacazes (1855)}

Se durante os primeiros anos de nascimento administrativo, ainda existia indefinição quanto aos projetos e às ações prioritárias para a cidade, a partir da década de 1840, as ideias divulgadas pela Câmara por meio dos jornais sugerem a escolha dos seguintes projetos ${ }^{29}$ : a construção dos canais do Uruguai, do Onça e de Campos-Macaé. Foi, portanto, no contexto de Brasil Império que as lideranças de Campos formulam melhor as suas demandas. O Monitor Campista, agora circulando duas vezes por semana (terças e sextas-feiras), se tornou um dos principais interlocutores 
dessas ideias, proclamando-se como o defensor dos cidadãos. Neste aspecto, se diferenciou do seu antecessor e originário $O$ Recopilador, cujo tom das matérias centrava-se nas discussões políticas travadas em nível nacional. O Monitor, sem se despreocupar com esta questão, se especializou em propagar as “mazelas” do município e divulgar os projetos da Câmara e dos cidadãos interessados no "progresso” da cidade. A sua estratégia de sensibilização consistiu na apresentação de matérias que ressaltavam o quadro "crítico" da cidade, em geral para difundir a ideia da necessidade de maior investimento por parte dos governos provincial e central. Assim, a construção social de um sentimento de abandono foi um dos mecanismos empregados para mobilizar a coletividade e justificar os apelos à Assembleia.

Por outro lado, sintonizado com as principais mudanças políticas na província, principalmente o debate sobre o novo regime de terra e o fim do tráfico de escravos, este jornal, adere aos projetos que visavam à regularização das terras dos considerados sertões no norte e noroeste de Campos. Em suas matérias, propõem-se, estrategicamente, os meios e instrumentos para integrar este vasto território, construindo estradas, canalizando rios, implantando freguesias e contratando empregados para exercer diferentes serviços nas áreas a serem desbravadas. A ideia em voga era expandir a produção agrícola mediante um controle fundiário deste sertão, até então habitado por posseiros, escravos quilombolas e índios. Propostas para melhorar a produção agrícola e modernizar os engenhos passaram, também, a ocupar papel no debate local, sobretudo porque, desde os anos de 1830, mas principalmente a partir dos anos de 1840, a cana-de-açúcar perde o seu papel de principal produto agroexportador da província.

A relativa queda da produção e a ascensão da região do café deslocaram geográfica e politicamente as forças políticas na Assembleia. Tal processo contribuiu para um sensível enfraquecimento das lideranças campistas junto à Assembleia, sem, contudo abalar o seu poder político, que permaneceu marcante neste fórum. Na realidade, a suposta crise na produção (suposta, pois neste contexto só atingiu os pequenos e médios proprietários) reforçou os argumentos sobre a necessidade de maiores investimentos na cidade para evitar a sua falência. Neste caso, o sentimento de abandono passou a ser cada vez mais acionado para justificar a importância de ampliar os investimentos. Portanto, mesmo dividindo o seu poder com as lideranças do vale do Paraíba, a força política da cidade ainda é uma realidade, manifestada, sobretudo, pela capacidade de recuperar recursos dos cofres provinciais e assegurar importantes obras, como foi o caso do canal CamposMacaé $^{30}$. Assim, a despeito da crise dos anos 1850, provocada pela escassez da mão de obra e a diminuição progressiva da produção do açúcar, Campos ainda era o município mais rico da província. A visita de D. Pedro II, realizada em março de 1847, ilustra, de certa forma, esse poder político e econômico ${ }^{31}$. 
Digno de nota é que as visitas do Imperador às cidades e vilas da província, de certa maneira, tornaram-se símbolos de reconhecimento por parte do poder central da importância política e econômica dessas localidades e, por isso, via de regra, os projetos de transferência da capital da província, nasciam (ou se cristalizavam) após estas visitas. Com isso, o roteiro do Imperador, ao mesmo tempo em que se tornou um signo da importância de algumas cidades, em muitos casos engendrou as disputas pelo título de capital.

De alguma forma, a partir da década de 1850, as disputas pelo título de capital se acirraram no Rio de Janeiro, o que revela os conflitos locais e regionais por maiores recursos e visibilidade política e uma maior organização das bancadas regionais junto à Assembleia. ${ }^{32}$ Foi por isso, que o desejo de ser capital não se manifestou apenas em Campos, mas em várias cidades da província que acreditavam que essa mudança de estatuto poderia ser um caminho para resolver os seus problemas políticos e econômicos. Este é o caso, por exemplo, de Petrópolis, que no ano de 1855, às vésperas da visita do Imperador, apresentou um projeto à Assembleia provincial. Sobre tal proposta, o jornal A Pátria no ano de 1855, fazia a seguinte observação:

Não é Petrópolis um ponto commercial, não é um centro de mais facil communicação com os diversos lugares da provincia, não é um lugar afastado da Côrte e immediações, não é ainda um termo favorecido por grandes elementos da lavoura; porque, pois, mudar para Petropolis a capital da provincia? (A PÁTRIA, 16/09/1855, p.1).

Concluindo esta matéria, o editor defendia a mudança da capital para Cabo Frio, em função do lucrativo comércio propiciado pelos rendimentos de sua alfândega.

Assim, o desejo de Campos se tornar a capital de uma nova província nasce desses movimentos: de um real poder político e econômico da cidade e de sua região de entorno (em especial a cidade de Macaé) frente ao acirramento das disputas regionais; de uma propaganda sistemática dos líderes locais junto ao governo provincial e central sobre a riqueza de Campos e a necessidade de ampliá-la por meio de obras; e, finalmente, de um maior poder político das novas camadas sociais, que pouco a pouco assumiam cargos políticos e administrativos na municipalidade, tornando-se os novos propagadores das ideias de ampliar o progresso e a civilização em Campos.

O movimento inicial é deflagrado pelo vereador José Fernandes da Costa Pereira ${ }^{33}$, ao requerer em 1855 à Câmara Municipal de Campos, a nomeação de uma comissão especial para recolher dados estatísticos e topográficos do município e informações sobre a sua produção e população, visando formular um projeto para ser submetido aos poderes da Província e do Império. A intenção era transformar a Comarca de Campos em província, estabelecendo, então, como sua 
sede (capital), a cidade de Campos. A configuração territorial desta província incluía a vila de Itapemirim, no Espírito Santo e as vilas e povoados dos considerados sertões do Pomba e Carangola, circunscritos nos limites da província de Minas Gerais (Ver Mapa) ${ }^{34}$. Como no requerimento estava escrito que todas as vilas eram favoráveis à criação da província de Campos, o vereador Costa Pereira solicitou que essas adesões fossem concretizadas em memoriais dirigidos às autoridades provinciais e imperiais. A Comissão nomeada para redigir a representação era integrada pelo barão de Carapebus ${ }^{35}$, o Cônego Angelo José da Fonseca e o próprio Costa Pereira.

\section{Projeto da província de Campos de Goytacazes (1855)}

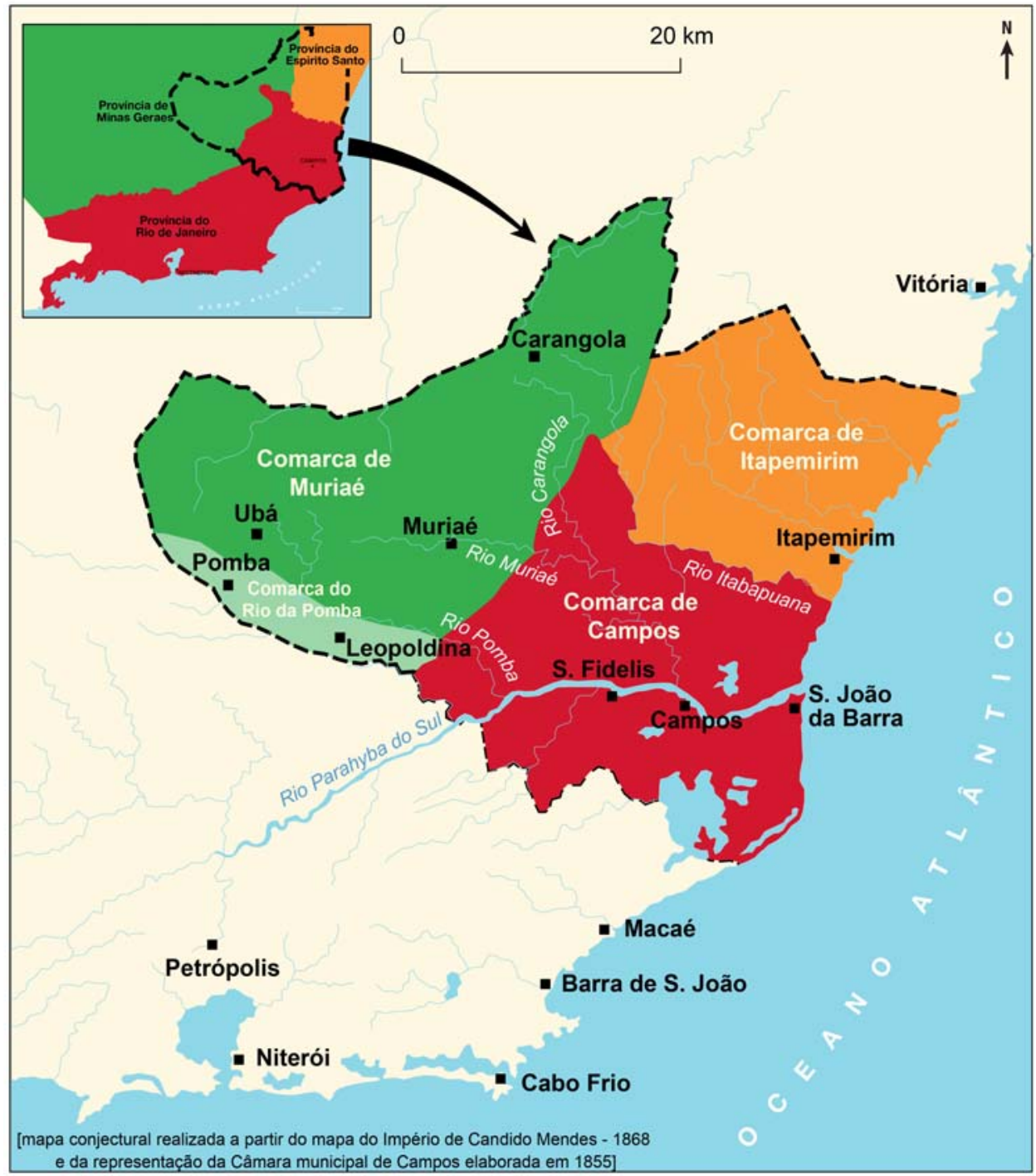

Nesta Representação, apresentada à Câmara no dia 14 de julho de 1855, e assinada por todos os vereadores ${ }^{36}$, descrevia-se o seguinte sobre a cidade: Campos distava de Niterói 70 léguas e tinha uma população de cerca de cem mil habitantes, com território de 500 léguas quadradas. A 
cidade ocupava uma posição favorável para o desenvolvimento das vilas e povoados que se localizam nos limites das províncias do Rio de Janeiro, Minas Gerais e Espírito Santo.

E si a creação da provincia é necessria em algum logar para commodidades dos povos, para o desnvolvimento da agricultura, commercio, e artes, e para o progresso e civilizasão, de todos esses germens de riqueza e felicidade que por todo o Brasil existem, em nenhuma o é certamente mais do que em Campos dos Goytacazes, sobre tudo attendo-se á proximidade das matas, pertencentes a provincia de Minas, que hoje se acham também convertidas em municípios, aos quaes para Campos é mais commodo incomparavelmente para entreterem suas relações, faltado-lhe sómente para isso boas vias de communicação para o interior, o que não teremos em quanto Campos não for o centro de uma província, em que de perto possam promover esses melhoramentos. (Extrato da Representação dos vereadores da Câmara de Campos, editado no jornal A PATRIA, 5/08/1855, p.3).

A Representação colocava, também, que o solo de Campos e de toda a região da Comarca era fértil e a expressiva produção agrícola da cidade poderia ser ampliada, caso as áreas do entorno fossem incorporadas a essa nova província.

A fertilidade de seu solo que parece renovar-se todos os annos; a abundancia de todos os víveres, que abastecem seus mercados; a sua longa extensão, população, industria, e activo commercio desta cidade; a sua communicação com o mar por via de um rio navegável; a sua riqueza e ainda mais a do seu incomparável município [...]. (Extrato da Representação dos vereadores da Câmara de Campos, editado no jornal A PATRIA, 05/08/1855, p. 2-3).

Os transportes e o comércio da cidade, animados pelos vapores que circulavam nos rios, disponibilizavam alimentos e produtos advindos de vários pontos de toda Comarca. É por esta razão que, na perspectiva dos propositores, a criação dessa nova província era um caminho para ampliar ainda mais capacidade de circulação de produtos e pessoas, pois a ideia era aproveitar a capacidade de importação e exportação por meio dos portos que existiam na extensa rede fluvial que circunscrevia esta Comarca.

Banhada pelo magestoso Parahyba, que já havendo recebido todos os rios e canaes, que lhe são tributários, a maior parte nageveis, entretem um navegação constante de barra, fôra, de cerca 60 embarcações de vela, e 2 vapores, exportando gêneros de toda comarca, e de todas as industrias. (Representação da Câmara de Campos, editado no jornal A PATRIA, 5/08/ 1855, p.3).

A Representação destacava as rendas provenientes do comércio e a sua produção agrícola, assinalando que ultrapassavam a quantia de seis mil contos de réis. As que eram arrecadadas pelo governo provincial por meio das coletorias chegavam a quase 100 contos de réis, quantia que poderia duplicar se fossem acrescentadas as rendas provenientes da exportação do café. Do outro 
lado, o desejo de ser uma província era um reconhecimento de um sentimento de ordem, união e ilustração que caracterizava o povo campista, ou seja, o fato da cidade ser reconhecida por manter um clima de tranqüilidade entre os seus habitantes. Os equipamentos urbanos e as instituições, como o teatro, o hospital de caridade, o Liceu Provincial, além dos dez templos e edificações elegantes, também foram exemplificados nesta Representação para assinalar o grau desenvolvimento e ilustração da cidade.

O Marquês de Paraná, presidente do Conselho de Ministros, tornou-se um entusiasta da ideia e fazia o seguinte pronunciamento em discurso no Congresso: "Penso que no norte da Província do Rio de Janeiro a cidade de Campos podia ser a capital da Província de Goytacazes”. (RODRIGUES, 1988, p.76) O presidente da Câmara dos Deputados, Dr. Antônio Francisco de Almeida Barbosa, também aderiu a esta ideia, e se tornou um defensor oficial da pretensão do deputado Joaquim Francisco Vianna. ${ }^{37}$ Mello (1886) informa que o senador João José Carneiro da Silva em "Noticia Descriptiva do Município de Macahé” ressaltava a riqueza da região e, acerca da criação desta província, fazia o seguinte comentário:

A criação da provincia de Campos e o estabelecimento do commercio directo do porto de Macahé - são os dous pontos objectivos a que tendem todos os espíritos que se ocupam com os interesses geraes desta importante e auspiciosa zona. Toda esta região foi outr'ora conhecida de campos dos Goytacazes e é portanto de justiça que o nome da nova provincia recorde estes tempos primitivos. Assim também Campos pela sua posição central, pela importancia do seu atual movimento commercial e agricola, está no direito de aspirar a ser a capital da nova provincia. Macahé, pelo seu porto, já bom e susceptível de ser ainda optimo, e por achar-se no ponto onde vêm affluir todas as vias férreas existentes e projectadas, está predestinada a ser o empório commercial e manufatureiro da nova provincia. Esta nova provincia, tendo em attenção os laços hoje criados pela sede das estradas de ferro, devia abranger os municipios de Macahe, Santa Maria Magdalena, São Fidelis, Campos, São João da Barra e Barra de São João. E além disso essa parte da provincia de Minas que há de ser influenciada pelas estradas. (RODRIGUES, 1988; apud, 1833, p.91-93).

Apesar do jornal A Pátria não ter sido o único a concordar com a demanda dos campistas, manifesta, nitidamente, o seu apoio à proposta. Na matéria, era colocado que apesar de afastada da capital, a cidade de Campos além de ter o comércio mais desenvolvido do que Niterói tinha crescido totalmente independente das influências da Corte.

A cidade de Campos está, se não mais adiantada em commercio e civilisação, ao menos a par da cidade de Nictheroy. O commercio ali é feito em grande escala, e crescedissimo, e a industria, mais do que em Nictheroi se tem desenvolvido, Ella tem a vantagem de se não achar a um tiro de distancia da capital. (A PATRIA, 5/08/1855, p.2). 
A existência da nova província estaria, para o redator, justificada pela necessidade de aproximação dos povoados localizados nos sertões de Minas e Espírito Santo, atualmente afastados da administração, da civilização e do mercado.

[...] sabe-se que uma das mais importantes condições de ordem, progresso e civilização para as provincias e povoações, é que dos diversos ramos do poder, se faça sentir; e que a industria e commercio recebam aquelle grau de impulsão que pode alargar o seu desenvolvimento. (A PATRIA, 5/08/1855, p.2).

Desdobrando este argumento, assinalava que a criação da província dos Goytacazes contemplaria uma necessidade que todos os povos têm de serem melhor administrados. Neste caso, uma das grandes missões administrativas da nova província era interligar os povoados localizados nas fronteiras da cidade de Campos com Minas Gerais e Espírito Santo, quase todos carentes de vias de comunicação, de instituições do Estado e de meios para ampliar o seu comércio.

Para que isso tenha lugar, é mister que as distâncias sejam o mais possível diminuídas, além que as transações legitimas de toda espécie tenham a solução conveniente e desejável. Estabelecei os grandes povoados que vivam da industria e do commercio, permuttando os seus produtos, grandes e difficeis distancias, e tereis empedido a marcha regular de seu commercio, demoraraeis a sua civilisação, e difficultareis notavelmente a expansão de suas riquezas. (A PATRIA, 05/08/1855, p.2).

Portanto, esta matéria deixava explícita a concordância do redator com os argumentos utilizados na Representação da Câmara, notadamente os seguintes aspectos: a necessidade de ampliar o comércio e a indústria da região, a importância de controle administrativo dos novos povoados estavam situados nas fronteiras dos sertões de Minas e Espírito Santo e a necessidade de ampliar as vias de comunicação.

Segundo Rodrigues (op. cit), o apoio a esta proposta não foi manifestado apenas por matérias publicadas em jornais, pois se estruturou um movimento pró-emancipação da vila de Itapemirim, que enviou um abaixo-assinado com 84 assinaturas favoráveis à ideia.

Sobre este apoio da vila de Itapemirim, é importante assinalar que esse fato pode ter ocorrido em função das pressões do vereador José Fernandes da Costa Pereira, já que o mesmo era um importante representante político desta vila e grande proprietário de terras nesta região, notadamente nos Sertões de Pedra Lisa. O vencedor há muito tempo vinha propondo à Câmara e ao presidente da província a adoção de medidas para ampliar o lucrativo comércio de madeira e demais produtos, que eram abundantes naquela área. A expansão do café aumentou ainda mais o interesse de Costa Pereira em interligar essa região à cidade de Campos e ao porto de São João da Barra. Por isso que um dos primeiros projetos apresentados para a Câmara era o de construir o canal do Onça - 
estrada líquida que possibilitaria escoar parte da madeira e demais produtos para a Corte por intermédio do porto de São João da Barra. ${ }^{38}$ Mas o que também estava em jogo nesse apoio de Costa Pereira era o desejo de controlar as terras dos sertões do Pedra Lisa, ${ }^{39}$ pois além de existirem vários quilombos que ameaçavam “a tranquilidade e segurança” dos grandes e médios proprietários daquela região, havia a preocupação de controlar a ocupação dos terrenos onde existiam aldeias abandonadas, o que vinha gerando uma situação de instabilidade permanente. Talvez seja por isso que, na Representação, uma das propostas era à aproximação e regularização dos terrenos situados nas fronteiras ${ }^{40}$. Contudo, o vereador Costa Pereira não era o único que tinha interesse nestes sertões...

Além dos interesses dos grandes proprietários, observa-se, nesta Representação, a ideia, já de certa forma impregnada no espírito das lideranças políticas e intelectuais, de que o caminho para ampliar o poder político e econômico de uma cidade passava pela mudança de seu estatuto político. ${ }^{41}$ Assim, o desejo em se transformar numa província constituía-se em uma estratégia para aumentar os recursos financeiros e dar maior visibilidade política à cidade de Campos.

Ser a capital de uma nova província representava também a legitimação de uma relação que a cidade exercia junto ao seu entorno. Neste caso, os argumentos de que Campos ocupava uma posição estratégica e que possuía a maior riqueza apresentaram-se como as justificativas mais plausíveis para fortalecer os vínculos com as localidades, sobretudo o controle das áreas em litígio. Ampliar a capacidade de circulação dos rios e instalar uma rede de administração nessas localidades foram, portanto, decorrência desse projeto.

Quanto à escolha do nome que a nova província iria receber - "Província dos Goitacazes” -, o redator do jornal A Pátria oferece uma importante justificativa. Para ele, essa denominação era merecida em função do histórico papel que Campos exercia na região. Se Campos, como argumentava o redator do jornal, conseguira se desenvolver de forma autônoma e longe das influências da Corte, isso demonstrava que possuía uma vocação natural para espraiar essa riqueza.

Utilizando-se desses argumentos, o projeto deixava claro qual o papel destinado para cada vila e cidade incorporada aos limites da nova província, sob o comando da capital. Uma grande área seria responsável pela expansão do café e do açúcar, outra se dedicaria à produção de gêneros de subsistência, e finalmente, a última - a cidade de Macaé - em função da importância econômica e política, seria naturalmente o segundo empório comercial da nova província, depois da cidade de Campos.

Emerge desse esboço de planejamento regional uma ideia de hierarquia urbana, a partir da distribuição dos papéis exercidos por cada localidade. Portanto, a província dos Goytacazes foi 
pensada em termos de uma rede urbana, um espaço integrado, por meio do qual a capital exerce o seu papel de atrair e difundir os fluxos administrativos, comerciais, políticos e culturais

Afora os interesses em desenvolver uma economia de âmbito regional e ganhar maior visibilidade política, a Representação dos líderes de Campos demonstra a articulação dessa cidade às várias escalas de poder: a local, representada pelas lideranças campistas, de Macaé e São João da Barra; a regional, representada pelo presidente da Câmara dos Deputados, Dr. Antônio Francisco de Almeida Barbosa, que se aliou ao autor da proposta, o campista e deputado Joaquim Francisco Vianna; e a central (tendo como representante o Marquês de Paraná, presidente do Conselho de Ministros). Cabe ainda destacar o apoio obtido pelas elites das províncias de Minas e Espírito Santo, que se pronunciaram favoravelmente nos jornais de suas cidades (RODRIGUES, 1988). Neste caso, sugere-se que a articulação dessas escalas vincula-se ao papel de Comarca já exercido por Campos, isto é, a sua função de controlar as atividades administrativas, judiciárias e civis de municípios, localidades e vilas em seu entorno. Portanto, o desejo de ser província é um desdobramento político deste papel de cabeça de uma Comarca.

A articulação de Campos às diferentes redes de poder em torno desse projeto está demonstrada não só pela gama de adesões à proposta, mas também pelo fato dela não ter sido discutida primeiramente na Assembleia provincial do Rio de Janeiro. Mesmo havendo uma indefinição sobre as reais atribuições desse órgão, o fato dessa Representação ser dirigida ao Senado soa um pouco estranho, pois a supressão desse município iria causar um impacto econômico nas rendas provinciais.

O projeto da província, entretanto, não foi executado. pois, antes de sua votação, a cidade passou por uma fatalidade, sofrendo com uma epidemia que, em poucas semanas vitimou milhares de pessoas na cidade, provocando um expressivo déficit populacional. ${ }^{42} \mathrm{Com}$ esta tragédia, Campos perdeu em algumas semanas a sua imagem de cidade próspera e ganhou o título de cidade enferma. Contudo, se temporariamente o projeto de ser uma nova província foi abandonado, o desejo de ser uma capital permaneceu.

\section{$3^{\circ}$ Movimento: desejo de se tornar a nova capital do então Estado do Rio de Janeiro - 1860 -} 1890

Durante os anos de 1860 e 1870 ocorreram muitos debates em torno da mudança da capital da província, sendo esboçadas algumas propostas em Campos. Estas discussões refletiam de certa forma, a crise política e econômica do Brasil e da província do Rio de Janeiro a partir de 1870, já que se tratava de um momento em que as bases do sistema monárquico começavam a se esfacelar e 
cresciam as reivindicações de autonomia em diferentes regiões do território fluminense. Os políticos fluminenses organizavam-se em torno das propostas para salvar a lavoura do café e do açúcar e para aumentar os recursos municipais. Mesmo após a aprovação de uma lei auxiliando financeiramente os municípios, era notória a insatisfação dos entes locais com os rumos da política econômica imperial ${ }^{43}$. Um outro ponto de conflito entre os deputados dizia respeito à adesão do Imperador à campanha abolicionista, uma vez que muitos dos seus apoiadores eram contrários à libertação dos escravos ${ }^{44}$.

De certa forma, as propostas de mudança da capital representavam esta conjuntura de crise e a tentativa de solucionar os conflitos no nível dos municípios. Não é à toa que apesar das discordâncias sobre qual o município que sediaria o governo provincial, havia um consenso da necessidade de transferir a capital de Niterói para outra cidade.

Por outro lado, a partir dos anos de 1870 assiste-se a uma mudança no quadro urbano da província, pois nas cidades e vilas, as ideias de emancipação dos cativos, de construção de uma nova civilidade e de um novo ideal político, social, econômico e cultural se fortaleceram. Há, ainda que timidamente, uma relativa mobilidade das camadas sociais em decorrência do crescimento das atividades citadinas, tais como o artesanato, o pequeno comércio e os serviços. Em Campos esse novo cenário urbano foi impulsionado em função do crescimento das atividades comercias e de serviços, pela elevação da sua população e pela diversificação dos grupos sociais ${ }^{45}$, processos redefiniram o perfil social e econômico e as redes de poder na cidade. Há, neste contexto, uma maior dependência dos grandes proprietários das fazendas de açúcar em relação ao setor comercial. A ocupação desses grupos em novos espaços políticos e sociais, antes ocupados majoritariamente pelos grandes fazendeiros foi uma decorrência desse processo.

Simbolizando este novo papel social e político na cidade, foram estes agentes que protagonizaram a demanda de Campos para se transformar na nova capital da província durante a década de 1870. Neste movimento, a Associação Comercial de Campos exerceu um importante papel. Tornando-se representante das aspirações desses grupos urbanos, tal instituição foi uma das principais propagandistas da necessidade de modernizar a cidade e instituir novos valores sociais e urbanos. Uma nova urbanização, a implantação de novos serviços, propostas mais modernas de higienização, tudo isso vai compor a nova pauta de reivindicações dos grandes comerciantes, firmas comissárias e emergentes camadas urbanas. Como coloca Alves (2009), houve um deslocamento discursivo das elites campistas: de município agrícola e monarquista, pouco a pouco a cidade passa a ser representada como um importante polo comercial e urbano, notadamente após a implantação da luz elétrica, a primeira a obter o título na América Latina. 
Empregando os mesmos artifícios dos grandes agricultores do passado recente, os comerciantes elegeram os jornais e revistas locais para difundirem as suas ideias. O Diário de Campos, por exemplo, durante os anos 1870 fez uma propaganda sistemática para transferir a capital da província do Rio de Janeiro para a cidade de Campos. Apesar de não ser o único jornal a defender tal proposta, se destacou pelos argumentos nada imparciais utilizados para justificar as riquezas de Campos. Este aspecto pode ser verificado em uma matéria publicada no ano de 1875, na qual o editor afirmava que a riqueza de Campos sobrepujava a de todas as cidades da província e, por isso, era a cidade que merecia e deveria ser contemplada com o título de capital.

Como sinalizador dos novos tempos, a força do discurso higienista foi um aspecto importante no novo debate sobre a mudança da capital, tornando-se epicentro das discussões ligadas ao clima e à salubridade dos ambientes. Com isso, os argumentos para sediar a nova capital centravam-se nas características climáticas/sanitárias encontradas nas cidades que estavam se candidatando. Sobre este aspecto são ilustradas as justificativas encontradas pelos redatores do Diário de Campos para refutar os argumentos sobre o clima inadequado da cidade e a proposição de mudança da capital para mais amena - a região serrana do Rio de Janeiro. No ano de 1876, por exemplo, respondendo a uma matéria publicada no jornal o Globo, que defendia a transferência da capital para Petrópolis, Teresópolis ou Nova Friburgo em função das melhores condições climáticas, o redator respondia que o responsável pela matéria não conhecia a realidade de Campos, notadamente: “[...] a uberdade de seu solo, suas relações commerciais, sua vida intima e o que mais importa, a natureza do seu clima” (DIÁRIO DE CAMPOS, 31/03/1876, p.1, Matéria intitulada: “Mudança da Capital”).

Contestando, portanto, os argumentos para ele "bairristas" de que a cidade era um foco de doenças epidêmicas em função da natureza do clima e de ser pouco desenvolvida, o editor do Diário de Campos, assinalava alguns atributos que concorreriam para a sua escolha. ${ }^{46}$

Quando as duchas de Friburgo tiverem exercido sua acção calmante sobre o sistema nervoso do articulista do Globo, consulte desapaixonadamente os interesses da provincia do Rio de Janeiro e concordara comnosco que não é o espírito de bairrismo quem dicta nossas phases, mas sim os interesses palpitantes de uma provincia, e que Campos por seus melhoramentos materiaes, por sua excellente urberdade, por seus importantes estabelecimentos agrícolas será de certo a capital da provincia do Rio de Janeiro, se os timoneiros do estado refletirem de um modo esclarecido e justiceiro. (Idem , 31/03/1876, p.1, Matéria intitulada: “Mudança da Capital').

O diálogo com o jornal Globo sobre a mudança da capital não parou por aí, em 5/04/1876, mais uma vez o editor do Diário de Campos, contesta os argumentos sobre a preferência do 
articulista em relação às cidades serranas. Nesta matéria o jornal Diário de Campos acusava o Globo de distorcer a realidade para justificar a sua nítida propaganda de transferência da capital para uma destas cidades. Afirmava, portanto, que Campos continuava a reunir todas as condições para concorrer ao título de capital.

Não querendo discutir um assumpto para o qual não há opportunidade, apenas traçamos as presentes linhas como um protesto ao paralello, que se pretendeu estabelecer entre esta cidade e Theresopolis, que com excepção de seu clima frio, nenhuma vantagem pode offerecer sobre Campos para centro da admnistração"

[...] Para que a administração, na phase de Tholey, possa levar ás extremidades do corpo social aquella acção, que partindo do seu coração e voltando a elle dá vida ao mesmo corpo, é preciso antes de tudo meios fáceis e abundantes por onde se manifesta a actividade governamental. (Idem, 05/04/1876, p.1, Matéria intitulada: "Mudança da Capital”).

E, dando continuidade aos debates com o articulista do Globo, em matéria publicada em 12/04/1876, o referido jornal vai referendar a salubridade da cidade e se contrapor, veementemente à transferência para Teresópolis, apresentando os seguintes argumentos:

Campos é um lugar saudável, possuidor de um clima secco, igual, pouco sujeito ás variações rapidas de temperatura, e cujos habitantes chegão de ordinário a uma idade avançada no pleno vigor de suas faculdades (Idem, 12/04/1876, p.1, Matéria intitulada: "Mudança da Capital”).

Na perspectiva do redator do Diário de Campos, mudar a capital para uma das cidades serranas apenas comprovava o bairrismo de algumas lideranças na Assembleia, pois os locais propostos estavam situados em posição geográfica desfavorável, possuíam um terreno estéril e a população era reduzida. Portanto, após desconstruir esses argumentos, o redator do Diário de Campos concluía a sua defesa da seguinte maneira:

Estamos firmemente convencidos de que a mudança da capital da provincia não é uma questão de estatuto capricho, ou de enfezado bairrismo e mas sim melhoramentos de alto alcance politico e admnistrativo [...]

Terreno fertilíssimo em que a natureza aprouve ostentar toda beleza e variedade de suas riquezas; agricultura em florescência a matisar os prados com os subidos primores de seus innumeros productos; commercio leal, animado, febricitante a fecundar e a retemperar as vivas fontes de todos as industrias; elegantes edifícios a surgirem do solo como as magicas creações das antigas legendas; estradas de ferro a sulcarem o seio virgem das graciosas campinas e dos florestas seculares; instruç̧ão, foco de luz, imenso e inexhaurível, a illuminar a tudo e a todos, com os surprehendentes effeitos da mais esplendida aurora boa fé, valor e vontade, tudo isto Campos possue. E porque não será Ella a capital da provincia do Rio de Janeiro? (DIÁRIO DE CAMPOS, 12/04/1876, p.1, Matéria intitulada: "Mudança da Capital”). 
Os debates sobre a mudança da capital em Campos não terminaram por aí e foram apresentadas outras propostas, sobretudo quando se ampliaram os conflitos políticos entre os adeptos à continuidade da monarquia e os favoráveis a República ${ }^{47}$.

Foi neste ambiente marcado pelo fortalecimento das ideias republicanas, que novamente os representantes políticos da cidade de Campos anunciaram o seu projeto de ser a nova capital do Estado do Rio de Janeiro. Integrante ativo do movimento republicano fluminense, Francisco Portela, empresário e fazendeiro de Campos, se tornou um entusiasmado defensor da transferência da capital para Campos $^{48}$. Contudo, apesar de Francisco Portela ter sido nomeado o primeiro presidente republicano do estado do Rio de Janeiro, a proposta de Campos em se transformar na nova capital da República não foi aceita naquele momento. A ideia, entretanto permaneceu...

Em 1893, devido à crise do partido republicano e à busca de maior visibilidade dos seguidores de Francisco Portela, o debate sobre a capital renasce. Esta discussão reflete as disputas de poder envolvendo as lideranças políticas da cidade de Niterói, Campos e demais municípios. Neste cenário, novamente a cidade de Campos juntamente com Nova Friburgo se candidataram para ser a nova capital do Estado. O debate foi difundido por importantes jornais de Campos: $A$ República, A Gazeta e o Monitor Campista. Conforme discute Alves (2009) neste movimento um agente que se destacou foi a Associação Comercial de Campos, que encaminhou para a Assembléia Legislativa uma proposta assinalando as vantagens que a cidade oferecia ao estado do Rio de Janeiro se fosse à nova capital. Em tal proposta, a Associação se comprometia a participar do processo de construção de uma cidade-capital.

Alves (2009) aponta, ainda, que movimento pró-emancipação foi difundido na cidade por meio de uma peça teatral apresentada em 1893, intitulada “Campos-Capital”. Este projeto ganhou maior expressividade quando assumiu o tom de uma proposta regional, já que recebeu a adesão de alguns municípios do norte fluminense, como Macaé, Itaperuna, São João da Barra e São Fidélis. Neste processo, mais uma vez a proposta se encaminha para a transformação de Campos em um novo Estado. O projeto foi votado em 1894 e mais uma vez Campos foi derrotada, vencendo a cidade de Petrópolis. No entanto, a intenção de Campos se tornar a capital de um Estado não morreu e novos projetos foram apresentados pelos campistas no início da década de 20.

É, talvez, diante desse sentimento frustrado de ser capital que se possa compreender o slogan atualmente empregado pela prefeitura de Campos. 


\section{Problematizando a ideia de Campos-capital}

Os projetos de Campos em se transformar em capital mudaram ao longo do século XIX, tanto devido à mudança de seu papel político e econômico como em função das novas forças políticas que se impuseram no âmbito local e regional. Contudo, a despeito das mudanças no conteúdo das propostas de transformação da cidade em capital, um aspecto que caracterizou os projetos analisados consiste na similitude dos argumentos empregados pelos seus propositores. Guardadas algumas diferenças, de certa forma, o objetivo era fortalecer a rede de comunicação, visando integrar e controlar a produção e o consumo das localidades do entorno. Uma ideia que teve seu embrião nas propostas do capitão Couto Reys, elaboradas no final do século XVIII. Portanto, a matriz argumentativa dos projetos de capital apoiava-se na proposta de subordinação das localidades do entorno por meio da potencialização das vias fluviais e terrestres e na incorporação de novos terrenos.

Sugerido como chave do progresso regional, o discurso de transformação de Campos em capital forjou uma ideia de hierarquia urbana e novas configurações espaciais a partir da projeção e da criação de uma rede de comunicação. Desta forma, os projetos para ser uma capital coincidiram com o movimento de formação e consolidação de uma rede urbana capitaneada pela cidade de Campos. Neste caso, o desejo recorrente em se transformar cidade-capital traduzia a intenção de fortalecer as relações de dependência econômica e política em nível local e regional.

Um dos aspectos que também caracterizou os movimentos em prol da capitalidade foi o postulado de que a cidade havia crescido de forma autônoma, ou seja, em função de uma vocação natural dos campistas ao desenvolvimento. Neste movimento, memórias, livros, relatos, jornais e revistas contribuíram significativamente para edificar a figura do campista, esculpida por um sem número de relatos, como o de guerreiro, quase um herói, que desbravou as matas e transformou a vila com sua força e persistência num lugar aprazível e ocupado por gente “sociável”, “patriótica” e “afeita à festa”. Este discurso, no entanto omitiu a realidade, pois a cidade sempre foi beneficiada direta e indiretamente pelo Estado, especialmente nos anos iniciais do Império. Contudo, tal aspecto sempre foi manejado para convencer os demais grupos que disputavam recursos sobre a necessidade de promover melhorias naquela região. Após o nascimento e a multiplicação dos jornais na região, os apelos em prol da cidade se especializaram ainda mais.

Pode-se dizer, que os projetos para se tornar capital demonstravam o desejo de maior visibilidade política e econômica da cidade e, por isso, representavam o esforço dos líderes políticos em se manterem no centro das decisões da antiga província do Rio de Janeiro. Assim, sinalizavam as estratégias dos seus autores em transformar os atributos físicos e sociais de um espaço em um 
dado positivo. Neste aspecto, criar uma capital tornou-se, antes de tudo, um ato de representar os espaços, aspecto instaurador da valorização/desvalorização de determinados lugares em relação aos outros. Por isso que paralelamente à projeção ideológica desses novos “lugares centrais”, o que estava em jogo era o poder de intimidação e convencimento de determinados grupos e o seu desejo em se manter no poder. Um aspecto que coloca em evidência o conceito de centralidade, enquanto uma condição social historicamente construída.

Os argumentos empregados para transformar a cidade de Campos em capital sugerem, portanto, a reflexão sobre os processos sociais indutores de complementaridades políticas e econômicas que se estruturam a partir de interesses ligados a produção, consumo e circulação de bens, reprodução, controle e vigilância dos grupos sociais. Compartilha-se, então, das análises feitas por Raffestan (1993) quando discute a ideia da rede associada ao processo de transformação dos espaços em territórios, portanto como um instrumento de poder.

Observa-se, nesse sentido, que os projetos de capital apresentados por Campos refletiam os desejos de construção e desconstrução dos espaços em função dos interesses de alguns grupos sociais de controlar as rotas, a população e os recursos em nível regional, isto é a intenção de se apropriar de espaços para estabelecer uma modalidade de domínio. Esse processo foi marcado pela produção de um discurso espacial e a criação de uma imagem positiva. Um ato que como analisa Chatier, (1990), substitui o real por uma “imagem” que vai se reconstituir em memória. Pode-se dizer que o conceito de capital acionado pelas lideranças de Campos na maior parte das vezes demonstrava essa habilidade dos grupos sociais em forjar a história e a memória de um lugar e, neste movimento, reconstruir uma imagem nem sempre real da cidade.

Via de regra, a noção de escala vai ser empregada pelos agentes do progresso para produzir esta imagem e justificar seus projetos de capital. Este é o caso das áreas de entorno da capital, quase sempre representadas como longínquas, vazias e prontas para um novo investimento. Como analisa Moraes (2005), quase todas as representações sobre o território produzidas durante o período colonial e imperial, expressavam os interesses em transformar "zonas de domínio incompleto” ou “áreas estagnadas ou decadentes” em um território urbanizado, seja com projetos visando a sua integração, seja a partir da instalação de um serviço de administração. O objetivo era promover a aproximação e/ou o contato. Os projetos apresentados por Campos não fugiram a essa regra. Utilizando-se de uma operação discursiva, as propostas de capital sempre apregoavam a importância da proximidade para diminuir a distância (social e espacial) da hinterlândia de Campos. Ser, portanto, uma capital, representou uma busca por redefinir novas fronteiras espaciais frente à necessidade de ampliar o poder econômico e político e resolver as diferentes crises enfrentadas na cidade. 


\title{
Notas
}

\begin{abstract}
${ }^{1}$ Atribui-se ao bom desempenho da economia açucareira no século XVIII até as primeiras décadas do XIX no Rio de Janeiro, o apoio governamental e a evolução dos preços no mercado internacional, sobretudo nos períodos de conflito que ocorreram nos Estados Unidos após a sua Independência e quando a produção das Antilhas francesas diminuiu (1780 a 1806). Portanto, a recuperação e destaque nas exportações do açúcar a partir de 1790 relacionavam-se aos seguintes fatores: a) investimentos contínuos do Marquês de Lavradio e de Luis de Vasconcelos e Sousa, b) maior quantidade de engenho em relação à Bahia e a Pernambuco, c) maior grau de inovação da produção, d) ocupação de novas terras em direção à Angra e Parati e ao sul e ao norte Campos, e) maiores investimentos na ampliação dos
\end{abstract} engenhos e estabelecimento de novas unidades a partir de 1796. Wehling (1982)

${ }^{2}$ Com a autorização dos Vice-Reis, as visitas das autoridades eclesiásticas buscavam recolher informações gerais sobre a região e a possibilidade de se criar novas freguesias, paróquias e aldeamentos.

3 Este ator teve a função de racionalizar o uso das terras supostamente devolutas e propagar a ordem. Portanto, associados ou não as ordens religiosas, os mestres de campo assumiram um grande poder nas localidades, exercendo funções militares, administrativas e fiscais. Quem assumiu o comando inicial no Distrito Administrativo de Campos foi o Mestre de Campo João José Barcelos Coutinho, que era proprietário de vários engenhos.

${ }^{4}$ Vale ressaltar que o desempenho econômico da área esteve atrelado a muitos conflitos de poder em torno da posse da terra iniciados em meados do século XVI, quando então os colonizadores ocupam a região. Por sua vez, a luta pela implantação da vila foi um processo historicamente marcado pelas várias tentativas de fundação, iniciada desde o século XVII. A partir do século XVIII, entram em relativo acordo os maiores proprietários, entre eles os herdeiros da família Asseca, os padres jesuítas e beneditinos e os grandes fazendeiros, o que culmina na instalação do poder na região.

${ }^{5}$ Como indicava Pizarro (1822) em sua "Informação da Capitania”, o vice-rei Marquês do Lavradio relatava ao seu sucessor que durante muitos anos a região de Campos era asilo de ladrões, assassinos e malfeitores, que lá viviam em total liberdade, desconhecendo as regras da sujeição. Ele relatava as medidas adotadas para impor a ordem na região, como os investimentos na contratação de funcionários e o incentivo à prática do comércio, da lavoura e da agricultura, assim como a distribuição de sesmarias e a criação de comarcas, distritos, freguesias, capelanias e aldeias. Para ele isto teria surtido um efeito positivo, pois nos últimos dez anos a região estava se desenvolvendo.

${ }^{6}$ Conforme ainda Soffati (1997), Manoel Martins do Couto Reys nasceu na vila de Santos por volta de 1750. Ele seguiu uma longa carreira militar, notabilizando-se como cartógrafo, pois foi responsável pela elaboração de mapas de várias cidades da província do Rio de Janeiro, como Campos, Cabo-Frio, e a Memória e Carta inacabada da Fazenda de Santa Cruz. Em sua visita a Campos, ele foi responsável pela elaboração de um dos mapas mais detalhados do século XVIII. Para seu entendimento, redigiu um texto explicativo que mostrava os vários aspectos assinalados no mapa que se intitulava "Descrição Geográfica, Política e Cronográfica do Distrito dos Campos Goitacás.

${ }^{7}$ Este documento, que à época revelava uma visão utilitária da natureza e da sociedade, foi construído quando o capitão fez uma longa expedição em Campos e registrou minuciosamente vários aspectos da cidade e da área de entorno, como o nascimento das suas freguesias e povoados, as atividades econômicas e os hábitos sociais. Tal narrativa, além de ser, talvez, o mais detalhado perfil socioeconômico e ambiental daquela cidade no século XVIII, pode ser considerado um projeto social de ocupação, já que aponta os meios necessários para tornar tal região mais próspera.

${ }^{8}$ Conforme argumenta Moreira (2002), após a promulgação da Lei de Terras, em 1850, muitas das terras indígenas adquiridas por sesmarias anteriormente doadas, passaram a ser interpretadas como devolutas. Tal fato tanto levou a sua apropriação legal por parte do Estado Imperial, como a sua incorporação aos vários projetos de ocupação, como por exemplo, os núcleos de colonização que foram implantados na região. Em Campos essa estratégia pode ser observada em grande parte dos terrenos que eram aldeias indígenas.

${ }^{9}$ Escrito em 1819 o livro intitula-se "Memoria Topografica e Histórica sobre Campos dos Goitacezes com uma noticia breve de suas producções e commercio offerecida ao mui poderoso Rei e Senhor Nosso D. João $6^{\circ}$. Por Natural do Mesmo Paiz”. Carneiro Silva era filho do capitão Manuel Carneiro da Silva e da fidalga Ana Francisca de Vellasco Tavora de Barcellos Coutinho. Tanto seu avô como seu pai foram capitães da aldeia dos índios em Quissamã, ou seja, eram responsáveis pela administração das terras indígenas na região. Estabeleceram grande fortuna na área em função do cultivo da cana-de-açúcar em uma sesmaria que ia da Lagoa Feia à lagoa da Ribeira. Neste local, a família ergueu, entre 1777 e 1782, a casa da fazenda Mato de Pipa, que hoje é a mais antiga casa de Senhor de Engenho da região Norte Fluminense, e, por isso, tombada pelo Inepac em 1985.

${ }^{10}$ A atuação política dos grandes fazendeiros do interior da província do Rio de Janeiro e de Minas Gerais no início do século XIX relacionou-se também ao seu papel de distribuidor de produtos alimentares que abasteciam a Corte. Para viabilizar tal abastecimento, algumas estradas foram abertas e/ou ampliadas. (Lenharo, 1993). 
${ }^{11}$ Ribeiro (2008, apud OLIVEIRA, 1996) analisa as bases deste apoio, demonstrando que simbolizavam tanto o interesse de alguns grupos em conquistar uma melhor posição no mercado interno e na administração como o temor de uma rebelião por parte das camadas mais pobres. Protegidos pelas redes de parentesco, que ocupavam os principais postos administrativos da Coroa, tais grupos defendiam a nacionalização do comércio, outrora monopolizado por representantes mercantis de Portugal. Contudo, tais forças políticas não eram contrárias à Independência e nem à permanência das práticas monopolistas em relação ao comércio interno.

12 Sodré (1999) assinala que o papel assumido pela imprensa não se diferenciava muito neste contexto, ou seja, guardadas as características locais e regionais, de certa forma, os jornais do início dos anos 1830 tinham como traço característico a resistência inicial ao Regresso e nos anos 1840, a sua adesão a outros grupos que se instalaram no poder. Citando as observações de Otávio Tarquínio de Souza, Sodré (op cit) assinala que a imprensa neste contexto podia ser identificada a partir de sua adesão às ideias conservadoras, liberais e moderadas.

${ }^{13}$ Antes, em 1826, teve nascimento o Espelho Campista - de Prudêncio Joaquim Bessa - considerado o primeiro jornal em Campos e em $1^{\circ}$ de janeiro de 1831 foi impresso o seu $1^{\circ}$ número. Mello (1886), por sua vez, informa que o primeiro periódico da vila data de janeiro de 1831 e seu nome era O Correio Constitucional Campista. Segundo ele: “era um jornal patriota, e seu redactor principal era o Dr., Francisco José Alipio, medico distincto e de muita reputação, que morreu assassinado. O Sr. Commendador José Gomes da Fonseca Parahyba auxiliava-o nessa tarefa.” (op cit, p. 100). Assinala que Campos foi uma das primeiras cidades a ter um jornal, ele informa que dos anos 1830 até a data de publicação do seu livro (1886) existiam em Campos, os seguintes jornais: O Campista (1834), Diario Commercial de Campista , Recopilador Campista, Monitor Campista, Cruzeiro, Conciliador, Sentinella da Constituição, Revista da Sociedade Phenix Literaria, Ordem, Regeneração, O Paiz, Independente, Alvorada Campista, Despertador, A Abelha, O Pury, O Goytacaz, A Verdade, Ortiya, Gazeta de Campos, Borboleta, Amolador, Artista, Pernilongo, Infancia, Diario de Campos, Futuro, Correio de Campos, Commercio de Campos, O Regenerador, Gazeta do Commercio, Jornal da Provincia, Diario Popular, Matraca, Situação, Lux (literário). Mello aponta, ainda, a existência de outros jornais que tiveram existência efêmera.

${ }^{14}$ A província assim como a cidade foi estabelecida por meio do Ato Adicional de 1834. Nomeado em 20 de agosto de 1834, Joaquim José Rodrigues Torres, o visconde de Itaboraí, foi quem inaugurou sua vida política, dando os primeiros passos para a organização administrativa e judicial. A Assembleia Provincial, composta por trinta deputados, reunia as figuras da mais alta projeção regional e nacional como Evaristo Ferreira da Veiga, João Paulo dos Santos Barreto, José Clemente Pereira, Paulino José de Sousa Soares.

${ }^{15}$ Mello (1886) informa que em função de conflitos de terra e disputa em torno da criação da vila de Campos, D. José ordenou que a capitania da Parahyba do Sul fosse incorporada aos limites da capitania do Espírito Santo em $1^{\circ}$ de junho 1753. Foi concedida ao seu donatário em compensação, uma pensão anual de 3.000 cruzados. “A Villa de São Salvador desde então até 1832 gozou de paz e no remanso da tranqüilidade foi-se povoando, desenvolvendo a sua agricultura, e conquistou em breve logar importante entre suas co-irmãs”. (op, cit, p.100).

${ }^{16}$ Incorporam-se aos limites da província, os territórios de Campos, São João da Barra, Parati e Cantagalo. Do ponto de vista econômico, a inserção destes territórios consagrou política e economicamente o Rio de Janeiro, pois estas áreas se destacavam pela grande produção de café e açúcar.

${ }^{17}$ Neste contexto persistia a dúvida no Senado sobre a necessidade ou não do Rio de Janeiro se tornar uma província e ter uma administração própria, ou seja, havia uma discussão sobre a pertinência de ter um Conselho provincial na Corte. Portanto, existia o receio de alguns senadores de que o representante político dessa nova província não estivesse preparado para assumir a administração de uma área tão estratégica para o Império. Receava-se, também, a exemplo, do Marquês de Caravelas, que o presidente do Rio de Janeiro ofuscasse o poder do Imperador. "O chefe Supremo da Nação precisa de ter seus delegados nas outras provinciais; mas não do Rio de Janeiro onde tem seu Ministro, e Conselho de Estado - Tal presidente só servirá para conflitos com os ministros, e se mostraria roda desnecessária da Administração” (Extrato do Debate do Senado publicado no Diário do Rio de Janeiro, no. 8)

${ }^{18}$ Uma das importantes discussões que ocorreram no século XIX dizia respeito ao papel político e administrativo dos municípios. Tal debate ganhou centralidade após a promulgação do Ato Adicional de 1834, que reforçou ainda mais a situação de centralização nos entes locais. Duas tentativas para tentar modificar a extrema centralização foram feitas durante a década de 1860. A primeira foi uma lei apresentada pelo Marquês de Olinda, em 1862, e a segunda em 1869, por Paulino Soares de Sousa. Ambos eram ministros do Império quando apresentaram os referidos projetos de reforma. Estes, não tiveram suporte, e mesmo se fossem aprovados, não introduziriam modificações substancias na forma como as províncias interferiam na vida administrativa dos municípios. (Chrysostomo, 2006 e 2010)

${ }^{19} \mathrm{O}$ movimento do Regresso, desenrolado entre os anos de 1840 e 1841, caracterizou-se pelo papel assumido pelos políticos fluminenses nas medidas de ordem administrativa e política que foram implementadas para fortalecer o poder do Imperador, tais como: a elaboração da Lei de Interpretação do Ato Adicional; a reforma do Código de Processo Criminal e a lei do Conselho de Estado. Conforme coloca Iglésias (1993), a denominação de Regresso foi dada em oposição ao Progresso, amplamente pregado nos oitocentos pelos liberais. As medidas do Regresso ganharam corpo com a renúncia de Diogo Antônio Feijó.

${ }^{20}$ Em homenagem ao Imperador, a principal rua da cidade - “A Beira Rio” - passou a ser denominada de rua Pedro II. 
${ }^{21}$ O Monitor Campista é atualmente o terceiro jornal mais antigo em circulação do país. Conforme Feydit (1900) o jornal era a continuidade do antigo Campista, nascido em 4 de janeiro de 1834, e o Monitor, cujo primeiro número saiu em julho de 1838. No entanto, segundo Horácio Souza (1935), o Monitor Campista nasceu da fusão do Campista, fundado por Bernardino José Maciel em 4 de julho de 1838, e gerido em 1840, pelo suíço Eugéne Bricolens e Thomé José Ferreira Tinoco e o Recopilador Campista.

${ }^{22}$ Segundo Feydit (op.cit), a notícia de elevação de São Salvador dos Campos para a condição de cidade chegou no dia 4 de abril e foi bastante comemorada. Quando emancipada, encontrava-se habitada por cerca de sete mil moradores, com uma dúzia e meia de pequenas ruas estreitas e tortuosas, seis travessas - quase todas sem pavimentação e crivadas de atoleiros - uma precária iluminação pública, uma praça e quatro largos.

${ }^{23}$ Sobre este aspecto, Soffiati (2005) coloca que houve uma: “[...] explosão de projetos desenvolvimentistas elaborados pelas elites rurais e urbanas neste contexto, a exemplo do realizado por José Carneiro da Silva do século XIX e o de Henrique Luiz de Niemeyer Bellegarde, chefe da $4^{a}$ Seção de Obras Públicas da Província do Rio de Janeiro no século XIX”.

${ }^{24}$ Não foi encontrado nenhum debate no Recopilador Campista sobre a questão da mudança da capital. Este jornal, contudo publica o Decreto de criação desta cidade e as providências que deveriam ser tomadas em função desse novo estatuto.

${ }^{25}$ Conforme afirma Gouvêa (op. cit), a legislação de 1857 e de 1861 indicava que Campos era o município que mais arrecadava imposto para os cofres municipais, além de ser o que mais possuía empregados municipais. Niterói, por sua vez, era o que mais gastava com despesas de pessoal. A situação privilegiada da cidade levou a uma deliberação da Assembleia, de que Campos não necessitava de ajuda financeira dos cofres do Rio de Janeiro.

${ }^{26}$ A pesquisa revelou que em $88 \%$ dos casos, os deputados representavam os interesses de sua localidade. Conforme sua análise, apesar de Campos ter tido o maior número de ligações com os deputados, à medida que o tempo vai passando, a cidade vai perdendo essa posição para outras regiões da província, notadamente o Vale do Paraíba em função da grande produção de café.

${ }^{27}$ Cabe ainda lembrar que de 1821 a 1830, o açúcar era o principal item de exportação do Rio de Janeiro (30,1\%), seguido do algodão (20,6\%) e do café (18,4\%). De 1831-1840, o açúcar passa para 24,0\%, o algodão para 10,8\% e o café para $43.8 \%$.

${ }^{28}$ Gouvêa (2008) revela que, em 1838, a província arrecadou 124:284\$. As três cidades que mais arrecadaram impostos foram Campos, responsável por (21:824\$0, Niterói (9:800\$) e Itaboraí ( 9:300\$). No ano de 1851, Campos arrecadou 20:077\$; Niterói 12:100\$; Iguaçú 10:703\$. Cabe ressaltar que, nos anos seguintes, além de Campos destacar- se como grande arrecadadora, a cidade de Macaé, que até então era um distrito de Campos torna-se e uma forte aliada ao seu projeto político de se tornar uma capital , passando também a se sobressair em termos de arrecadação.

${ }^{29}$ Por intermédio do relatório da província, nos anos de 1841 e 1842, os projetos mais destacados foram o canal do Nogueira, a construção da muralha no rio Paraíba e a construção de pontes e pontilhões nas cidades.

${ }^{30} \mathrm{O}$ canal Campos-Macaé foi o primeiro que recorreu a recursos financeiros decorrentes da administração provincial. Para sua efetivação, várias leis e decretos foram promulgados e muitos projetos foram pensados. Por tal obra ter sido eleita desde o primeiro presidente da província como uma das mais importantes da província, foi firmado um contrato com o inglês, o Sr. Fresse. A repercussão local desta obra foi anunciada por $O$ Recopilador no ano de 1835, sendo divulgada uma carta do referido inglês em janeiro do mesmo ano, na qual ele conclamava os fazendeiros da região a participarem como sócios da futura empresa que pretendia fundar com o fim de iníciar as obras neste canal. Posicionando-se favoravelmente ao projeto, o editor do jornal fez o seguinte pronunciamento: "He dever de todo o bom patriota coadjuvar os esforços que se empreguem neste sentido; e nós annelamos os melhores resultados ao offerecimeno e projeto do Sr. Freeze" ( O Recopilador, 1835, p.2)

31 A viagem a Campos ficou marcada pela grande distribuição de títulos nobiliárquicos, comprovando, assim a importância dos políticos e fazendeiros. Em 1846, a Câmara Municipal foi comunicada por meio de uma portaria do Presidente da Província, Visconde de Sepetiba, a visita imperial, solicitando aos vereadores que tomassem providências. Houve a convocação extraordinária da Câmara e os líderes tomaram uma série de medidas emergenciais, não obstante a "estreitesa do tempo e falta de recurso do país". Assim, a estrada do Queimado e a Rua Direita começaram a ser consertadas. Os moradores da Rua Direita, das Flores e Praça Principal foram convidados para assearem as frentes de suas casas e as adornarem no dia em que por elas passassem S. Majestade. Recomendou-se também que durante a estadia do Imperador todas as casas fossem iluminadas à noite. (MELLO, 1886)

${ }^{32}$ Paralelo a este fortalecimento econômico e político da cidade, aumentaram as disputas regionais por mais recursos junto à Assembleia provincial, movimento este que encontra eco nos meios de comunicação local. Gouvêa (2008) assinala que a partir dos anos de 1850 uma nova geração de deputados, cada vez menos vinculados às demandas da Corte, passam a representar os interesses das localidades e de sua região de origem.

${ }^{33}$ Cabe ressaltar que este vereador (advogado e político) brasileiro foi um importante líder político do Império e um grande proprietário de terras em ampla região que abarcava a cidade de Campos e Espírito Santo. Este durante os anos 1860 e 1870 assumiu o cargo de presidente de várias províncias. Do Espírito Santo (1861 a 1863), do Ceará (de 20 de 
janeiro a 26 de abril de 1871), de São Paulo( 1871 a 1872), do Rio Grande do Sul( 1872). Foi também ministro dos Negócios do Império do Brasil, de 10 de março de 1888 a 1889.

${ }^{34}$ Durante quase todo o século XIX foi tema de muitos debates e conflitos os limites circunscritos entre a as províncias do Rio de Janeiro, Minas Gerais, São Paulo e Rio de Janeiro.

35 Joaquim Pinto Neto dos Reis foi o primeiro barão com grandeza de Carapebus. Grande fazendeiro e político da localidade, ele foi advogado e militar brasileiro, exercendo o posto de tenente-coronel comandante da Guarda Nacional. O seu título nobiliárquico de Barão foi concedido por D. Pedro II, por meio de carta de 2 de dezembro de 1854.

${ }^{36}$ Os nomes dos vereadores que assinaram a representação eram: Dr. Antonio Francisco de Almeida da Barbosa, João Martins Leão, Antonio Joaquim da Silva pinto, José Fernandes da Costa pereira, Francisco de Paula Gomes Barroso e os Conegos Angelo Jose da Fonseca, Agostinho dos Santos Collares e Manoel de Brito Coutinho. (FEYDIT, 1900).

${ }^{37}$ Este vereador era neto de Joaquim Vicente dos Reis, herdeiro do Solar do Colégio e um grande negociante e político do Império.

${ }^{38}$ Ele obteve recursos por subscrição popular e realizou a obra entre 10 de julho e 3 de novembro de 1840 . No ano seguinte, contudo, pela Lei n. ${ }^{\circ}$ 244, de 10 de maio, o governo provincial determinou que a Câmara Municipal de Campos indenizasse José Fernandes da Costa Pereira com a importância de quatro mil e seiscentos contos de réis e se tornasse proprietária do canal, encarregando-se de sua limpeza e conservação. Essa decisão decorreu de problemas na administração do canal.

${ }^{39}$ O Canal da Onça, acima dos sertões do Nogueira e de Imburi, situava-se entre os rios Muriaé e Itabapoana, região que se notabilizou pela produção de café, sobretudo a partir de 1840.

${ }^{40}$ Cabe ressaltar que anteriormente a esta data já havia planos para ocupação do Sertão de Pedra Lisa, sendo adotadas a partir de 1850 algumas medidas administrativas no sentido de dar um novo destino aquelas áreas, entre as quais, a designação de grandes extensões de terrenos como devolutos.

${ }^{41}$ Neste caso, não deixa de ser importante mencionar que no Império, os municípios não desfrutavam de autonomia política e administrativa, o que concorreu em muitos casos para a penúria financeira de muitos entes municipais.

42 O plano foi atrapalhado pela disseminação da "Cholera morbus", doença mortal que dizimou mil e duzentos habitantes apenas em dois meses (de 9 de outubro a 31 de dezembro, só na cidade, morreram 1.239 pessoas), e a epidemia ainda se alastrou por mais tempo. O impacto da doença foi tão expressivo que não havia nem tempo para enterrar os cadáveres, sendo estes empilhados em carroças. O governo da Província tentou medidas preventivas, nomeando uma comissão de médicos e o delegado de polícia para tentarem diminuir o alastramento da doença. Tais medidas ocorreram junto ao porto de São João da Barra - os passageiros vindos de fora foram impedidos de entrar em Campos para não espalhar a doença no Rio de Janeiro, o que foi inútil, pois a doença se espalhou. Foram improvisadas enfermarias no Liceu da Lapa e em São João da Barra, na foz do Paraíba. O delegado de polícia sugeriu que não mais se fizesse inumação de cadáveres nas igrejas nem no Cemitério da Misericórdia, pois estavam dentro do perímetro urbano.Tendo em vista esse quadro, a economia da cidade decaiu. (MELLO, 1886)

${ }^{43}$ Mesmo que em 1887 tenha sido suprimido o imposto sobre exportação do açúcar, beneficiando os proprietários rurais, a crise se ampliou ainda mais quando foi promulgado o regulamento de 1888, criando uma nova tabela de impostos sobre indústrias e profissões. Os comerciantes de Niterói e Campos, as maiores cidades fluminenses, entraram em atrito com o governo e se recusaram a pagar tal imposto.

${ }^{44}$ Cabe ressaltar que muitos dos republicanos contrários ao regime monárquico também argumentavam sobre a grave crise ocasionada à lavoura e à ordem pública, caso os escravos fossem libertados, portanto, também se opunham ao seu fim imediato.

${ }^{45}$ De acordo com Vasconcellos (2000), por volta dos anos de 1870, a cidade de Campos possuía 1 prado de corridas denominado Jockey Club, 1 matadouro público, 2 bancos, 2 companhias de seguros marítimos e terrestres, 1 estação telegráfica, 1 caixa econômica, 1 agência de correios, 5 hotéis, 4 trapiches, 3 tipografias, 3 periódicos, 15 estabelecimentos de instrução (públicos e privados), 1 quartel, 4 fábricas de fundição de máquinas para a lavoura, 3 fabricas de destilação, 1 serraria a vapor, 1 cortume, 1 oficina fotográfica, 1 casa de recolhimento dos órfãos, 3 lojas maçônicas, 6 cemitérios reunidos em um só ponto e com comunicação entre si, 1 templo presbiteriano, 15 igrejas. Em 1880 havia no município 58 advogados, 75 médicos, 4 engenheiros, 10 oficiais do exército, 4 da marinha e 67 sacerdotes. Além dos 10 viscondes e 16 barões, que constituíam a elite de Campos, também existiam 15 jornalistas e 13 literatos. Somados a estas categorias, havia profissionais que atuavam nas repartições públicas, como os enfermeiros, os mensageiros, tipógrafos, entre outros (ALVARENGA,1880).

${ }^{45}$ Em 1834, por exemplo, foi fundada a Caixa Econômica que funcionou até 1897, por um grupo liderado pelo cônego Mariano Leite da Silva Escobar como presidente e o Barão de Guarulhos como tesoureiro. O Banco de Campos foi fundado em 1863 e funcionou até 1899. No entanto, o banco mais importante foi o Banco Comercial e Hipotecário de Campos, mais conhecido como "Banco Vovô". Idealizado no ano trágico da "Cholera morbus" de 1855, somente foi inaugurado em 1873, tendo duração de mais de 80 anos. (Mello, 1886)

${ }^{46}$ Em síntese, o editor do jornal $O$ Globo discordava da transferência para a cidade de Campos, utilizando-se dos seguintes argumentos: o clima era abrasador, a planície vivia alagada e estava na maior parte das vezes úmida, a região não dispunha de boas estradas de terra; as construções eram de tijolos, pois não havia pedra por perto; não havia água, 
somente a do Paraíba e, mesmo assim, a água que existia tinha que ser depositada um ano e meio, pois em Campos não havia local para despejos. (O Globo, 1876, 26/03/1876)

${ }^{47}$ Ferreira (1989) relata que, durante o Congresso Republicano Provincial, realizado em 13 de novembro de 1888 foi fundado o partido Republicano fluminense. Neste evento foram lançadas as bases para combater a monarquia e um plano para apoiar os ex-proprietários de escravos dissidentes do sistema monárquico. Posteriormente, criaram-se mais de 30 clubes republicanos no Rio de Janeiro, o que teve impacto nas eleições para deputados. O partido Liberal, até então minoritário se fortaleceu principalmente após o apoio de alguns representantes do partido conservador.

${ }^{48}$ Participou também desta disputa a cidade Teresópolis.

\section{Referência}

ALVARENGA, João de. Almanack Industrial, Mercantil e Administrativo da cidade de Campos (Rio de Janeiro). Campos: Tipografia do Monitor Campista, 1881. Histórico, 1880.

ALVES, H. M. A Sultana do Paraíba - Reformas urbanas e poder político em Campos dos Goytacazes, 1890-1930. Rio de Janeiro: Arquivo Público do Estado do Rio de Janeiro, 2009.

CAMPOS, O. A imprensa na Velha Província: 170 anos do Monitor Campista - O terceiro jornal mais antigo do país e a morte misteriosa do jornalista Francisco José Alypio. Anuário Internacional de Comunicação Lusófona, 2004

CHARTIER, R. A história cultural: entre práticas e representações. Rio de Janeiro: Difel/Bertrand Brasil, 1990.

CHRYSOSTOMO, Maria Isabel de Jesus. Idéias em Ordenamento, cidades em formação: a produção da rede urbana província do Rio de Janeiro - 1840-1889, Tese de Doutorado, IPPUR/UFRJ, 2006.

Reformas Administrativas e Organização do espaço urbano na Província do Rio de Janeiro - 1808-1850. In: FRIDMAN, Fania (Org.). De Cidades e territórios. Rio de Janeiro: PoD Editora, 2010.

FEYDIT, J. Subsídios para a Historia dos Campos dos Goitacases. Campos, 1900

FRIDMAN, F.; CHRYSOSTOMO, M. I. J. Projetos territoriais para o império brasileiro: o caso da província fluminense. In: Revista Praia Vermelha. Rio de Janeiro,v.20nº1,p.157-168,Jan-Jun2010. FERREIRA, M. M. A república na velha província: Oligarquia e crise no estado do Rio de Janeiro (1889-1930). Rio de Janeiro: Editora: Rio Fundo. 1989.

IGLÉSIAS. F. Trajetória Política do Brasil: 1500-1964. São Paulo: Companhia das Letras, 1993.

FAORO, R. Os Donos do Poder: Formação do Patronato Político Brasileiro. Porto Alegre: Ed. Globo, v. 2, 1979.

LAMEGO, R. A. A Planície do Solar e da Senzala. Rio de Janeiro: Arquivo Público do Estado do Rio de Janeiro (Coleção Fluminense), 2ª edição, 1996.

.O Homem e o Brejo. Rio de Janeiro: Ed. Fac -similar: IBGE, 2007.

LENHARO, Alcir. As Tropas da Moderação. Rio de Janeiro: o abastecimento da Corte na formação política do Brasil - 1808-1842. Rio de Janeiro: Prefeitura da cidade do Rio de Janeiro, Biblioteca 
Carioca, 2a edição, 1993.

MELLO, J. A. T. Campos dos Goitacases em 1881. Rio de Janeiro: Laemmert, 1886.

MELLO. C. F. P. Os Corpos de Ordenanças e Auxiliares Sobre as Relações Militares e Políticas na América Portuguesa. História: Questões \& Debates, Curitiba, n. 45, p. 29-56, 2006. Editora UFPR. Acessado em 23/10/2010:

http://ojs.c3sl.ufpr.br/ojs2/index.php/historia/article/viewFile/7944/5593

MORAES, A. C. R. Território e História do Brasil. São Paulo: Annablume, 2a edição, 2005.

MOREIRA, V. M. L. Terras Indígenas do Espírito Santo, sob Regime Territorial de 1850. In: Revista Brasileira de História: Associação Nacional de História. 2002, p.153-169.

WEHLING, A. O açúcar fluminense na recuperação agrícola do Brasil. In RIHGB, no. 337-out. /dez, 1982. Brasília - Rio de Janeiro.

RAFFESTIN, C. Por uma Geografia do Poder. São Paulo: Ática, 1993.

REYS, Manoel Matinz do Couto. Manuscritos de Manuel Martinz do Couto Reys, 1785. Rio de Janeiro: Arquivo Público do Estado do Rio de Janeiro, 1997. (Transcrição do manuscrito original)

RIBEIRO, G. S. Nação e Cidadania no jornal O Tamoio. Algumas considerações sobre José Bonifácio, sobre a Independência e a Constituinte de 1823. In: RIBEIRO, G. S. (Org). Brasileiros e cidadãos: modernidade política -1822-1930. São Paulo: Alameda, 2008.

RODRIGUES, H. S. Campos: Na Taba dos Goytacazes. Niterói: Imprensa Oficial, 1988.

RIBEYROLleS, C. Brasil Pitoresco: História, Descrições, Viagens, Colonização, instituições. Ilustrado com gravuras de vistas, panoramas, paisagens, costumes, etc. por Victor Frond. São Paulo: Livraria Martins, $2^{\circ}$ volume, 1941.

SANTOS, M. A Natureza do Espaço: técnica e tempo, razão e emoção. São Paulo: Hucitec,1999.

SILVA, J. C. Memoria Topografica e Histórica sobre Campos dos Goitacezes com uma noticia breve de suas producções e commercio offerecida ao mui poderoso Rei e Senhor Nosso D. João $6^{\circ}$. Por Natural do Mesmo Paiz. Rio de Janeiro. Impressão Regia, 1819.

SOFFIATI, A. Propostas de desenvolvimento para o Norte-noroeste fluminense em Perspectiva Histórica. Revista VÉRTICES, v. 7, n. 1/3, jan./dez. 2005, acessado em 30/10/2010

SODRÉ, N. W. História da Imprensa no Brasil. São Paulo: Mauad, 1999.

SOUSA, A. M. Viagens e Observações de hum brasileiro que desejando ser útil á sua Patria, e os três reinos da Natureza, em varias lugares e sertões do Brasil, offerecidas á Nação brasileira. Rio de Janeiro: Impresso na Typ. Americana de I. P. da Costa. Tomo Primeiro, 1834.

PIZARRO E ARAUJO. J. S. A. Descripção Geographica, Politica e Cronographica do Districto dos Campos Goitacaz, Memórias Historicas do Rio de Janeiro, $3^{\mathrm{o}}$ volume , $2^{\mathrm{a}}$ Ed. Rio de Janeiro: Imprensa Nacional, 1945 (original 1820?) 
URUGUAY, V. Estudos Práticos sobre a administração das provincias no Brasil. Tomo I e II. Rio de Janeiro. B.L. Garnier, 1865.

VASCONCELlOS, F. Aspectos do desenvolvimento de Campos dos Goitacazes no século XIX. Comunicação ao XV simpósio de História do Vale do Paraíba. Série História, no. 7, Quatis, 2000.

Fontes primárias

O Recopilador Campista. Campos (RJ), Typ. Patriotica de Parahyba E Cia., 1835. Vol.1, 03/10/1835, Jan. a 30 dez. $\mathrm{N}^{\text {os }}$. 1-3, 5-6, 8-14, 16, 30, 33-37, 47, 51-63, 65-80, 83-96.

O Monitor Campista. Campos (RJ). Typ. Patriótica de Evaristo José Pereira da Silva e Abreu. 31 mar. 1840, 29 dez. 1840 - nos. 01-75, 31 dez. de 1841 - nos 76 - 176.

A Patria, Folha da Província do Rio de Janeiro, 16/09/1855 e 27/08/1855.

Diário de Campos - órgão dos Interesses do Commercio e da Lavoura. Propriedade de uma Associação Anonyima. Campos: Typografia A.D’Oliveira e Silva.18 31/03/1876, p.1, Matéria intitulada: "Mudança da Capital”), 05/04/1876, p.1, Matéria intitulada: “Mudança da Capital”), 12/04/1876, p.1, Matéria intitulada: "Mudança da Capital”)

Diário do Rio de Janeiro, Rio de Janeiro: Typografia do Diario, [1821-1878?] No.8, 11/06/1834).

O Campista. Typ. Patriotica de Parayba e Alypio, Campos. 1834.

O Globo: órgão dos Interesses do Commercio, da Lavoura e da Indústria. Rio de Janeiro, 12/04/1876

Recebido em: 08/02/2010

Aprovado em: 12/04/2011 